
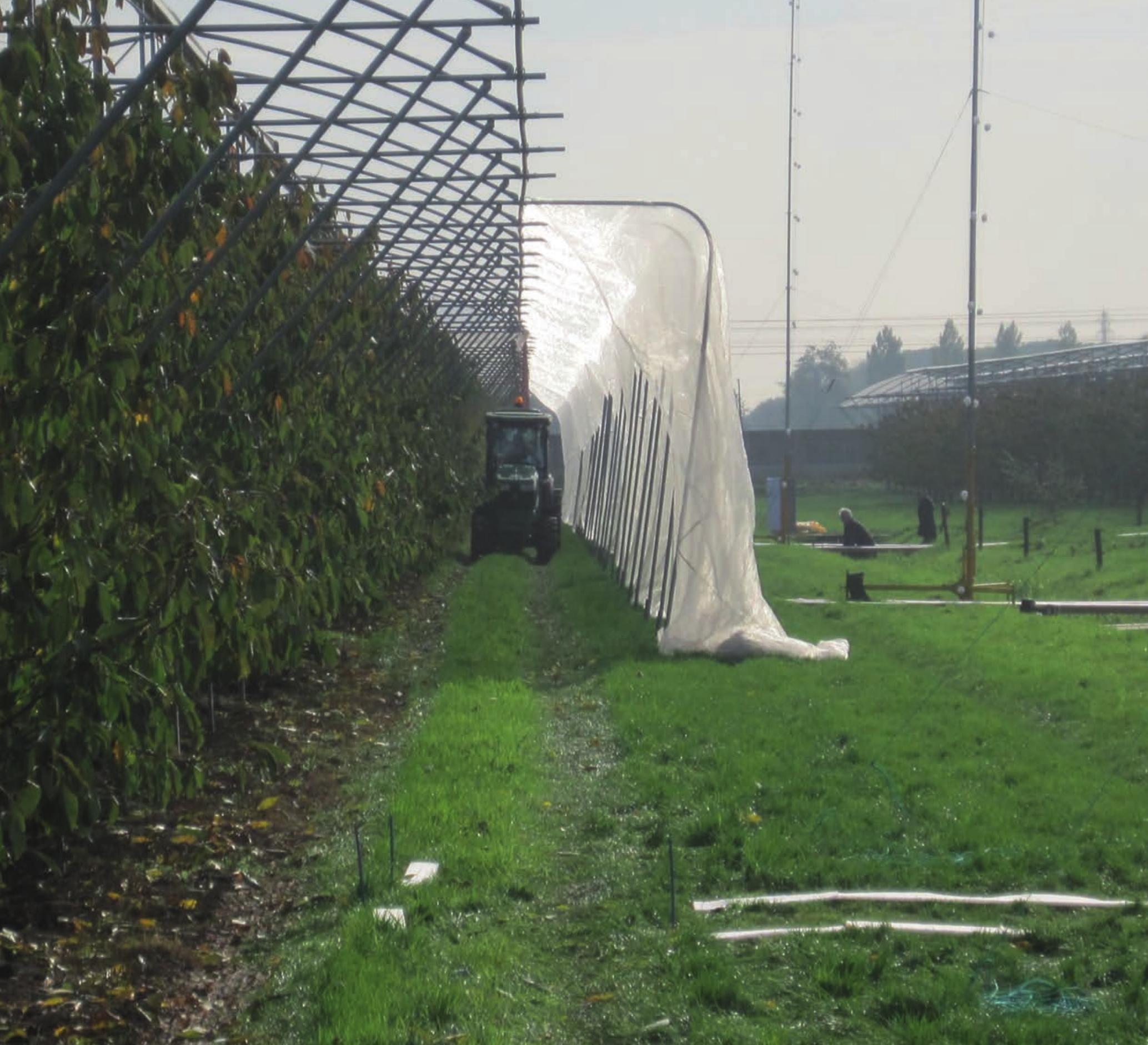

\title{
Emissiereductie door suzuki-fruitvlieggaas en regenkap
}





\section{Emissiereductie door suzuki-fruitvlieggaas en regenkap}

H. Stallinga, D.C. de Hoog, J.M.G.P. Michielsen, M. Snoussi, P. van Dalfsen, M. Wenneker \& J.C. van de Zande

Dit onderzoek is in opdracht van de Nederlandse Fruittelers Organisatie (NFO) uitgevoerd door de Stichting Wageningen Research (WR), business units Agrosysteemkunde en Open Teelten (projectnummer 3710464100) en mede tot stand gekomen dankzij financiering van de provincie Gelderland.

WR is een onderdeel van Wageningen University \& Research, samenwerkingsverband tussen Wageningen University en de Stichting Wageningen Research.

Wageningen, december 2019

Rapport WPR-960 
Stallinga, H., D.C. de Hoog, J.M.G.P. Michielsen, M. Snoussi, P. van Dalfsen, M. Wenneker \&

J.C. van de Zande, 2019. Emissiereductie door suzuki-fruitvlieggaas en regenkap. Wageningen

Research, Rapport WPR-960. 48 blz.; 11 fig.; 11 tab.; 18 ref.

Dit rapport is gratis te downloaden op https://doi.org/10.18174/518691

Results of spray drift experiments are presented for the effect of an insect net of equal height as the crop positioned at the outside of an orchard ( $3 \mathrm{~m}$ from the last tree row) and the combination of this insect net connected to a closed rain shield above the fruit crop. Spraying was done with a conventional crossflow orchard sprayer (Munckhof ECO cap) equipped with Very Fine standard hollow cone nozzles (Albuz ATR Lilac; 7 bar) and with a 95\% drift reducing technique (DRT95). The DRT95 was the same sprayer but equipped with 90\% drift reducing nozzles (DRN90; Albuz TVI8001, 9 bar), low air setting of the fan gear box and one-sided spraying of the outside tree row (only from outside inward). During the spray drift experiments the downwind outside $24 \mathrm{~m}$ of a cherry orchard was sprayed at the full leaf stage (BBCH 90/92) using the fluorescent tracer Acid Yellow 250. Spray drift deposition was collected downwind on a mowed grass area up till $25 \mathrm{~m}$ distance from the last tree row. Airborne spray drift was measured at $7.0 \mathrm{~m}$ distance from the last tree row on a pole at which two lines with collectors were attached at $1 \mathrm{~m}$ spacing up to $10 \mathrm{~m}$ height. At different zones for both application techniques the effect of the insect net on spray drift reduction was on average $53 \%-57 \%$ in comparison with both the spray application in the open situation. The spray drift reduction of the combination insect net at edge of field and closed rain shield above the fruit crop was on average $89 \%-92 \%$ for the two application techniques at different zones outside the treated field.

Airborne spray drift (0-10 $\mathrm{m}$ height at $7 \mathrm{~m}$ from last tree row) was reduced by positioning an insect net at $3 \mathrm{~m}$ from the last tree row with $26 \%$ for the standard spray application and $96 \%$ for the DRT95. The combination insect net at edge of field connected to the closed rain shield above the fruit crop resulted in airborne spray drift reductions of $67 \%$ for the standard application technique and $97,6 \%$ for the DRT95.

Key words: orchard sprayer, spray drift, nozzle type, air assistance, spray drift reduction, insect net, Drosophila suzukii, rain shield, fruit crop

(C) 2019 Wageningen, Stichting Wageningen Research, Wageningen Plant Research, Business unit Agrosysteemkunde, Postbus 16, 6700 AA Wageningen; T 03174807 00; www.wur.nl/plant-research

KvK: 09098104 te Arnhem

VAT NL no. 8113.83.696.B07

Stichting Wageningen Research. Alle rechten voorbehouden. Niets uit deze uitgave mag worden verveelvoudigd, opgeslagen in een geautomatiseerd gegevensbestand, of openbaar gemaakt, in enige vorm of op enige wijze, hetzij elektronisch, mechanisch, door fotokopieën, opnamen of enige andere manier zonder voorafgaande schriftelijke toestemming van Stichting Wageningen Research.

Stichting Wageningen Research is niet aansprakelijk voor eventuele schadelijke gevolgen die kunnen ontstaan bij gebruik van gegevens uit deze uitgave.

Rapport WPR-960

Foto omslag: Jan van de Zande (zande_DRT95-insectnet-rainshield-fruit_IMG_6869.JPG) 


\section{Inhoud}

Woord vooraf $\quad 5$

$\begin{array}{ll}\text { Samenvatting } & 7\end{array}$

$\begin{array}{ll}\text { Summary } & 9\end{array}$

$\begin{array}{lrr}1 & \text { Inleiding } & 11\end{array}$

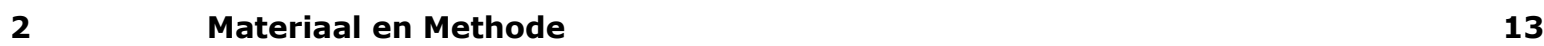

2.1 Beschrijving objecten en spuittechnieken 13

2.1.1 Beschrijving objecten 13

2.1.2 Karakteristieken Munckhof Eco kap dwarsstroom boomgaardspuit 16

2.1.3 Samenvatting gebruikte spuittechnieken 17

2.2 Beschrijving metingen en verwerking resultaten 19

2.2.1 Metingen 19

2.2.2 Analyses 20

$\begin{array}{ll}2.2 .3 \text { Berekeningen en statistiek } & 21\end{array}$

$\begin{array}{lll}2.3 & \text { Weersomstandigheden } & 23\end{array}$

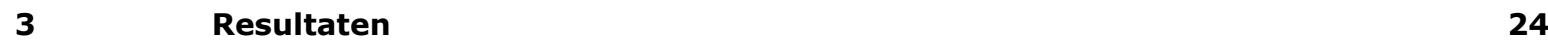

3.1 Drift naar de grond naast het perceel $\quad 24$

$\begin{array}{lll}3.2 & \text { Drift naar de lucht } & 27\end{array}$

$\begin{array}{ll}\text { Discussie } & 30\end{array}$

$5 \quad$ Conclusies $\quad 34$

Literatuur $\quad 35$

$\begin{array}{lll}\text { Bijlage } 1 & \text { Script statistische analyse } & 36\end{array}$

Bijlage 2 Weersomstandigheden tijdens de driftmetingen 37

Bijlage 3 Driftdepositie (\% van afgifte) op de grond naast het gewas 39

Bijlage 4 Driftdepositie (\% van afgifte) naar de lucht 45 



\section{Woord vooraf}

Emissie van gewasbeschermingsmiddelen verminderen is van groot belang voor de fruitteelt en speelt een belangrijke rol bij de invulling van beleid en regelgeving in Nederland. Toedieningstechnieken en maatregelen die de drift, het verwaaien van de spuitvloeistof tot buiten het doelgewas, reduceren zijn nodig om de beleidsdoelen te kunnen realiseren en om gewasbeschermingsmiddelen veilig te kunnen gebruiken. In deze rapportage wordt het onderzoek van de combinatie van driftreducerende maatregelen en standaard en een driftreducerende toedieningstechniek in de fruitteelt beschreven. Driftonderzoek is gedaan aan het effect van suzuki-fruitvlieggaas geplaatst aan de buitenkant van een boomgaard en de combinatie van dit gaas gekoppeld aan dichte regenkappen boven het fruitgewas waardoor een insectdichte omgeving ontstaat. De driftmetingen zijn uitgevoerd in een praktijkperceel in Echteld, met medewerking van WUR Open Teelten en WUR Unifarm.

Dit onderzoek is uitgevoerd in opdracht van de Nederlandse Fruittelers Organisatie (NFO) in samenwerking met Fruitpact en met medefinanciering van de Provincie Gelderland en begeleid door dhr. J. van Bruchem (NFO). Een speciaal woord van dank aan Gerrit van den Berg voor het beschikbaar stellen van de kersenboomgaard, en de ruimte eromheen en andere faciliteiten, de realisatie van de constructies in het veld en de hand en span diensten tijdens de driftmetingen.

Wageningen, december 2019 


\section{Samenvatting}

Om de invlieg van de suzuki-fruitvlieg (Drosophila suzukii) in de teelt van kersen, pruimen, druif en kleinfruit te voorkomen wordt aan de buitenkant van het perceel insectengaas gebruikt. Het insectengaas tegen de suzuki-fruitvlieg heeft een kleinere maasopening dan het gebruikelijk insectengaas. Bij de teelt van kersen wordt in de praktijk het suzuki-fruitvlieggaas aan de regenkappen bevestigd. Hierdoor ontstaat een afscherming tegen de suzuki-fruitvlieg waardoor de boomgaard vanonder deze constructie gespoten kan worden. Van het suzuki-fruitvlieggaas op de rand van het perceel en het suzuki-fruitvlieggaas bevestigd aan de regenkapconstructie wordt verwacht dat het tijdens bespuitingen ook de spuitdrift zal reduceren. Om de driftreductie van deze maatregelen te kwantificeren is een driftonderzoek opgezet met gebruik van twee toedieningstechnieken; een standaard spuit met standaard spuitdoppen en een standaard spuit met $90 \%$ driftreducerende spuitdoppen, lage luchtinstelling en eenzijdig spuiten van de buitenste bomenrij (DRT95). De driftmetingen werden dusdanig opgezet dat de resultaten voldoen aan de opgestelde eisen vanuit de toelating van gewasbeschermingsmiddelen ( $\mathrm{Ctgb}$ ), het Activiteitenbesluit Milieubeheer en internationale afspraken rondom meten en classificeren van drift (ISO22866, ISO22369).

De driftmetingen werden uitgevoerd door de buitenste $24 \mathrm{~m}$ ( 6 boomrijen, $4 \mathrm{~m}$ rijafstand) aan de benedenwindse zijde van een kersenboomgaard in het volblad stadium (BBCH 90/92) te bespuiten met de fluorescerende tracer Acid Yellow 250. De driftdepositie werd op een gemaaide grasstrook gemeten naast het bespoten perceel tot op $25 \mathrm{~m}$ afstand vanaf de buitenste bomenrij. De gebruikte collectoren waren filterdoeken (Technofil TF-290) van 0,50x0,10 m die aaneengesloten lagen van 2,5 m tot $15 \mathrm{~m}$ en filterdoeken van 1,00x0,10 m op $20 \mathrm{~m}$ en $25 \mathrm{~m}$ van de laatste bomenrij. De drift naar de lucht werd gemeten op 7,0 m van de laatste bomenrij met behulp van een mast tot $10 \mathrm{~m}$ hoogte met op elke meter hoogte een driftbolcollector (Siral Abdriftkollektoren).

Bij driftmetingen tijdens bespuitingen van een kersenboomgaard in het volblad stadium (BBCH 90/92) werd bij bespuitingen met ATR lila spuitdoppen en het plaatsen van suzuki-fruitvlieggaas op $3 \mathrm{~m}$ van de buitenste bomenrij, in vergelijking met de referentiebespuiting op de strook 41/2-51/2 $\mathrm{m}$ vanaf de buitenste bomenrij een driftreductie gevonden van 58,9\%. Door het plaatsen van suzuki-fruitvlieggaas in combinatie met dichte regenkappen werd een driftreductie gevonden van $88,6 \%$.

Bij driftmetingen met $90 \%$ driftreducerende TVI8001 spuitdoppen ( 9 bar), lage luchtinstelling en eenzijdig spuiten van de buitenste bomenrij (DRT95) werd in de open situatie een driftreductie gevonden van $92,1 \%$. Door het plaatsen van suzuki-fruitvlieggaas werd met deze techniek een driftreductie gevonden van $96,3 \%$. Door het plaatsen van suzuki-fruitvlieggaas en dichte regenkappen werd met deze techniek een driftreductie gevonden van 99,3\%.

Door het plaatsen van suzuki-fruitvlieggaas is ten opzichte van de open situatie de gemiddelde driftreductie bij bespuitingen met TVI 8001 spuitdoppen (DRT95) ten opzichte van de open situatie gemiddeld 52,9\% hoger dan de driftreductie van de DRT95 techniek op zich. Hierdoor kan gesteld worden dat de driftreductie voor alle technieken gecombineerd met suzuki-fruitvlieggaas gemiddeld $55,9 \%$ is en dus één DRT-klasse hoger vallen.

Door het plaatsen van suzuki-fruitvlieggaas en regenkappen is de driftreductie bij de bespuitingen met TVI 8001 spuitdoppen (DRT95) 90,5\% hoger dan de driftreductie van deze techniek in de open situatie. Gemiddeld voor beide technieken was de driftreductie door suzuki-fruitvlieggaas en regenkappen $89,6 \%$. Hierdoor kan gesteld worden dat alle technieken gecombineerd met suzukifruitvlieggaas en regenkappen zeker twee DRT-klassen(standaard), maar mogelijk drie driftreductieklassen (DRT95) hoger vallen. 
De drift naar de lucht (gemiddeld over 0-10 m hoogte op $7 \mathrm{~m}$ afstand van de laatste bomenrij) werd door het plaatsen van suzuki-fruitvlieggaas bij bespuiting met de ATR lila spuitdoppen 26\% gereduceerd ten opzichte van de open situatie. Door het plaatsen van suzuki-fruitvlieggaas en dichte regenkap was de driftreductie naar de lucht $67 \%$. Bij bespuiting met de TVI8001 spuitdop (DRD90), lage luchtinstelling en eenzijdig spuiten van de buitenste bomenrij (DRT95) was de driftreductie naar de lucht (0-10 m hoog) in de open situatie 95,5\%, door het plaatsen van suzuki-fruitvlieggaas $96,1 \%$ en door plaatsing van suzuki-fruitvlieggaas en dichte regenkap 97,6\%. 


\section{Summary}

To protect fruit crops like cherries, plums, grapes and small fruits from the inflight of the Spotted Wing Drosophila (SWD) (Drosophila suzukii) insect nets are positioned at the edge of the field. Insect nets against suzuki-fruitfly have a smaller mesh than commonly used insect nets. In cherry growing the SWD insect net is attached to the outside edge of the rain shield positioned above the fruit crop, creating a shielded environment around the total orchard. The cherry trees are sprayed from inside this shielded environment. It is expected that the positioning of the SWD insect net at the edge of the field and the combination of the SWD insect net attached to the rain shields reduces spray drift. To assess and underpin this expectation WUR performed spray drift field experiments in a cherry orchard assessing the effect of an insect net of equal height of the crop positioned at the outside of an orchard ( $3 \mathrm{~m}$ from the last tree row) and the combination of this insect net connected to a closed rain shield above the fruit crop. Application techniques used were a conventional crossflow orchard sprayer (Munckhof ECO cap) equipped with Very Fine standard hollow cone nozzles (Albuz ATR Lilac; 7 bar) and with a 95\% drift reducing technique (DRT95). The DRT95 was the same sprayer but equipped with $90 \%$ drift reducing nozzles (DRN90; Albuz TVI8001, 9 bar), low air setting of the fan gear box and one-sided spraying of the outside tree row (only from outside inward). Spray drift experiments were setup to fulfil the requirements to provide proper data for the authorisation procedure of Plant Protection Products (Ctgb), the Environmental Decree (TCT protocol) and international protocols on spray drift measurements and its classification (ISO22866, ISO22369).

During the spray drift experiments the downwind outside $24 \mathrm{~m}$ of a cherry orchard ( 6 tree rows, $4 \mathrm{~m}$ row spacing) was sprayed at the full leaf stage (BBCH 90/92) using the fluorescent tracer Acid Yellow 250. Spray drift deposition was collected downwind on a mowed grass area up till $25 \mathrm{~m}$ distance from the last tree row. Filter collectors were used (Technofil TF-290) on ground surface of sizes $0.50 \times 0.10 \mathrm{~m}$ in a continuous row from $2,5 \mathrm{~m}$ to $15 \mathrm{~m}$ and of $1.00 \times 0.10 \mathrm{~m}$ at $20 \mathrm{~m}$ and $25 \mathrm{~m}$ distance from the last tree row. Airborne spray drift was measured at $7.0 \mathrm{~m}$ distance from the last tree row on a pole at which two lines with collectors (Siral Abdriftkollektoren) were attached at $1 \mathrm{~m}$ spacing up to $10 \mathrm{~m}$ height.

Results of the spray drift experiments show that at $4 \frac{1}{2}-5 \frac{1}{2} \mathrm{~m}$ distance from the last tree row the standard application technique, using the ATR lilac nozzles, in combination with the SWD insect net, spray drift reduction was $58.9 \%$. The combination SWD insect net and the closed rain shield at the edge of the field resulted in a spray drift reduction of $88.6 \%$. During the spray drift measurements, the DRT95 technique resulted in a spray drift reduction of $92.1 \%$ in the standard orchard situation. In combination with the SWD insect net the DRT95 resulted in a spray drift reduction of $96.3 \%$ at 4.5-5.5 m from the last tree row. The combination SWD insect net connected to the closed rain shield above the fruit trees at the edge of the field resulted in a spray drift reduction of $99.3 \%$.

For both application techniques (standard and DRT95) the effect of the SWD insect net on spray drift reduction was $58.9 \%$ and $52.9 \%$ respectively in comparison with both the spray application in the open situation. The spray drift reduction of the combination SWD insect net at edge of field attached to the closed rain shield above the fruit crop was $88.6 \%$ and $90.5 \%$ for the two application techniques.

Airborne spray drift (0-10 $\mathrm{m}$ height at $7 \mathrm{~m}$ from last tree row) was reduced by positioning a SWD insect net at $3 \mathrm{~m}$ from the last tree row with $26 \%$ for the standard spray application and $96 \%$ for the DRT95. The combination SWD insect net at edge of field connected to the closed rain shield above the fruit crop resulted in airborne spray drift reductions of $67 \%$ for the standard application technique and $97,6 \%$ for the DRT95. 


\section{$1 \quad$ Inleiding}

De emissie van gewasbeschermingsmiddelen verminderen is van groot belang voor de fruitteelt (VW et al., 2007) en speelt een belangrijke rol bij de invulling van Duurzame Gewasbescherming (EZ, 2013), het Activiteitenbesluit Milieubeheer (I\&W, 2017) en de toelating van gewasbeschermingsmiddelen (Ctgb, 2018). Doel van de Nota Duurzame Gewasbescherming (EZ, 2013) is verminderen van de overschrijding van de milieukwaliteitsnormen voor gewasbeschermingsmiddelen in oppervlaktewater tot nagenoeg nul. Hierbij moet het aantal overschrijdingen van de milieukwaliteitsnormen voor gewasbeschermingsmiddelen in oppervlaktewater in 2023 met 90\% afgenomen zijn ten opzichte van die in 2013. Om dit te realiseren moet op alle percelen de toediening van gewasbeschermingsmiddelen met minimaal 75\% driftreducerende technieken (DRT) uitgevoerd worden. Hierbij stelt het Activiteitenbesluit Milieubeheer (I\&W, 2017) dat voor de fruitteelt de teelvrije zone bij een DRT75 minimaal 4,5 m moet zijn. Als een $3 \mathrm{~m}$ teelvrije teeltvrije zone gebruikt wordt moeten gewasbeschermingsmiddelen met een minimaal 90\% driftreducerende techniek (DRT90) uitgevoerd worden.

Daarnaast is ook bij de toelating van gewasbeschermingsmiddelen de driftdepositie op wateroppervlak en de evaluatiezone voor niet-doelwit planten en arthropoden van belang. Het College voor de Toelating van Bestrijdingsmiddelen en Biociden (Ctgb) neemt beslissingen, onder andere op basis van de inschatting van de effecten op het milieu (Ctgb, 2018). Hierbij is het nodig te weten hoeveel van het middel in het oppervlaktewater terecht komt. Het Ctgb heeft de resultaten van emissie-onderzoek (Zande et al., 2019) ingedeeld naar driftreducerende techniek klassen (DRT) opgenomen in een drifttabel (Ctgb, 2018). In tabel 1.1 is voor de DRT-klassen DRT75 tot DRT99 zoals gebruikt in de fruitteelt voor de kale boom situatie (voor $1 \mathrm{mei}$ ) en de volblad situatie (na 1 mei tot $50 \%$ bladval) in driftdepositie weergegeven bij een teeltvrije zone van $3 \mathrm{~m}$.

Tabel 1.1 Driftdepositie (\% van uitgebracht spuitvolume per oppervlakte-eenheid) op wateroppervlak (3 m teeltvrije zone, 4,5-5,5 $\mathrm{m}$ vanaf buitenste bomenrij) van driftreducerende technieken (DRT) in verschillende klassen in de kale boom (voor 1 mei) en de volblad (na 1 mei) situatie (naar: Ctgb, 2018).

\begin{tabular}{lrr} 
Driftreducerende techniek groot fruit & Driftpercentage [\%] & kaal \\
\cline { 2 - 3 } Standaard & 16,6 & 8,6 \\
\hline DRT75 & 2,0 \\
\hline DRT90 & 1,0 \\
\hline DRT95 & 2,5 & 1,3 \\
\hline DRT97,5 & 1,3 & 0,36 \\
\hline DRT99 & 0,13 \\
\hline
\end{tabular}

De emissie van gewasbeschermingsmiddelen in de fruitteelt is hoog ten opzichte van andere teeltsectoren. Dit wordt onder meer veroorzaakt door de opgaande en horizontale spuitrichting en de vaak krachtige luchtondersteuning bij fruitteeltspuiten waardoor veel spuitvloeistof door het bladerdek van de bomenrijen heen gespoten wordt. Om drift te beperken zijn verschillende techniek- en teeltmaatregelen mogelijk. Technische maatregelen kunnen bestaan uit doptype, afscherming en luchtondersteuning. Een teeltmaatregel is bijvoorbeeld het aanleggen van een windsingel (windhaag), of het aanleggen van een teeltvrije zone waardoor de afstand tussen het te bespuiten gewas en het oppervlaktewater vergroot wordt, en de drift naar het wateroppervlak af zal nemen. Emissie naar de lucht (druppels en damp) bij gewasbespuitingen wordt in de toelating van middelen of het Activiteitenbesluit Milieubeheer momenteel niet in ogenschouw genomen. Uit metingen is gebleken dat bespuitingen met neveldoppen een aanzienlijke drift naar de lucht tot gevolg kunnen hebben (Michielsen et al., 2007, Zande et al., 2014). Deze emissie kan relevant zijn voor milieubelasting op grotere afstand van 
percelen, of consequenties hebben voor de aanwezigheid van bijvoorbeeld omwonenden en bebouwing (Gezondheidsraad, 2014).

Om de invlieg van de suzuki-fruitvlieg (Drosophila suzukii) in de teelt van kersen, pruimen, druif en kleinfruit te voorkomen wordt aan de buitenkant van het perceel insectengaas gebruikt. Het insectengaas tegen de suzuki-fruitvlieg heeft een kleinere maasopening dan het gebruikelijk insectengaas. Bij de teelt van kersen wordt in de praktijk het suzuki-fruitvlieggaas aan de regenkappen bevestigd. Hierdoor ontstaat een afscherming tegen de suzuki-fruitvlieg waardoor de boomgaard vanonder deze constructie gespoten kan worden.

\section{Doel van het onderzoek}

Van het suzuki-fruitvlieggaas op de rand van het perceel en het suzuki-fruitvlieggaas bevestigd aan de kapconstructie wordt verwacht dat het tijdens bespuitingen ook de spuitdrift zal reduceren. Om de driftreductie van het suzuki-fruitvlieggaas op de rand van het perceel en van de suzuki-fruitvlieggaas + regenkapconstructie combinatie te kwantificeren is een driftonderzoek opgezet met gebruik van twee toedieningstechnieken; een standaard spuit met standaard spuitdoppen en een standaard spuit met $90 \%$ driftreducerende spuitdoppen, lage luchtinstelling en eenzijdig spuiten van de buitenste bomenrij (DRT95).

De driftmetingen werden dusdanig opgezet dat de resultaten voldoen aan de opgestelde eisen vanuit de toelating van gewasbeschermingsmiddelen (Ctgb), het Activiteitenbesluit Milieubeheer (I\&W, 2017) en internationale afspraken rondom erkenning van driftmetingen (ISO22866, 2005; ISO22369, 2006). In deze rapportage worden de uitgevoerde driftmetingen beschreven van de twee spuittechnieken in een open boomgaard situatie en in de situaties met suzuki-fruitvlieggaas aan de buitenkant van het perceel en met suzuki-fruitvlieggaas en dichte regenkap tijdens bespuitingen van een kersenboomgaard in het volblad (na $1 \mathrm{mei}$ ) stadium. In hoofdstuk 2 wordt de proefopzet besproken, daarna volgen in hoofdstuk 3, 4 en 5 respectievelijk de resultaten, discussie en conclusies. 


\section{Materiaal en Methode}

\subsection{Beschrijving objecten en spuittechnieken}

In paragraaf 2.1.1 staat een beschrijving van de verschillende objecten (constructie/spuittechniek) en 2.1.2 de karakteristieken van de in de proeven gebruikte Munckhof ECO kap dwarsstroom boomgaardspuit.

\subsubsection{Beschrijving objecten}

In een veldonderzoek is in 2019 de drift vastgelegd van 3 objecten:

1. Open kappen (=standaard)

2. Open kappen met suzuki-fruitvlieggaas

3. Dichte kappen met suzuki-fruitvlieggaas aan de buitenkant

Het gedeelte van de kersenboomgaard met de regenkap open dient als standaard bespuiting. Hierbij wordt ervan uitgegaan dat de staanders en schoorstangen van de kapconstructie de spuitdrift niet negatief beïnvloeden. Bij het object met het suzuki-fruitvlieggaas (Howitec Netting - Ornata Air Plus 77102; maaswijdte 0,77×1,02 $\mathrm{mm}$, draaddikte doorsnede 0,23 mm) op de rand van het perceel, stond het gaas verticaal op $3 \mathrm{~m}$ van de laatste bomenrij zodat er tussen de laatste bomenrij en het gaas doorgereden kon worden. Aan de bovenkant was het gaas bevestigt aan een extra uitstekende hulpstang aan de regenkap constructie, die open was. Per regenkap staander was ook een verticale stang geplaatst om het gaas tijdens de bespuiting vast te houden. Aan de onderkant van het gaas was het gaas vastgelegd met zandzakken tegen het opwaaien van het gaas door de luchtondersteuning van de spuit tijdens passeren. Bij het object met dichte regenkap en suzuki-fruitvlieggaas was het suzuki-fruitvlieggaas op identieke manier bevestigd als bij object 2 maar was de regenkap dicht getrokken. Bij dichte regenkap ontstaat zo een bijna continu gesloten plastic dak met een smalle spleet $(20 \mathrm{~cm})$ voor de regenwater afvoer midden boven de grasstroken tussen de bomenrijen.

In figuur 2.1 staan schematische weergaven van de 3 objecten. In figuur 2.2 staan een aantal foto's van de 3 objecten met meetopstelling. 


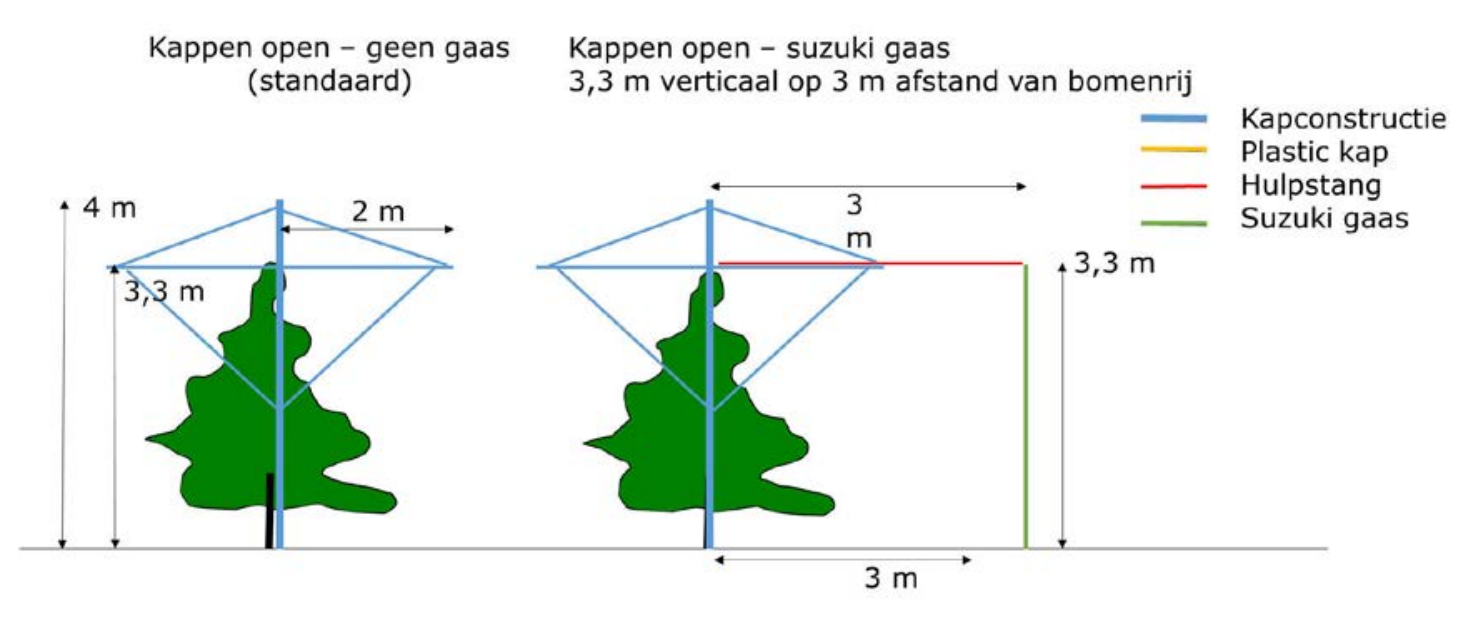

Kappen dicht - suzuki gaas buitenkant

3,3 $\mathrm{m}$ verticaal op $3 \mathrm{~m}$ (boven) afstand van bomenrij

en aangesloten op buitenrand van dichte kap constructie

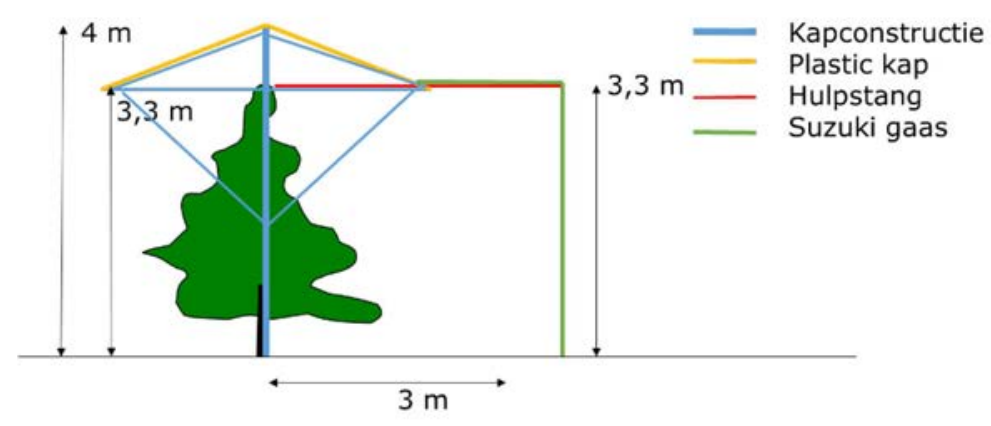

Figuur 2.1 Schematische weergave van de open kappen, open kappen met suzuki-fruitvlieggaas en de dichte kappen met suzuki-fruitvlieggaas aan de buitenkant.

Door de schuinstaande schoorstangen van de kapconstructie is met name aan de buitenkant de doorrijhoogte beperkt. Hierdoor kon de standaard dwarsstroomspuit, zoals in eerder fruitteelt driftonderzoek als referentiespuit gebruikt (TCT, 2017b), niet gebruikt worden in deze situaties.

De bespuitingen werden daarom uitgevoerd met een Munckhof (halfhoge, 2,40 m hoog) ECO kap dwarsstroom boomgaardspuit (figuur 2.4) waarbij de luchtrichting en de spuitrichting in plaats van dwars meer omhoog gericht is. De ventilator en de luchtopbrengst van de ECO kap spuit is identiek aan die van de Munckhof dwarsstroom spuit met DWK kap (fruitteelt referentie spuit; TCT, 2017b). Aan de bovenkant van de ECO kap zitten luchtgeleidingskleppen (figuur 2.4). Deze kleppen waren zo afgesteld dat de luchtstroom ervoor zorgde dat de spuitvloeistof van de bovenste spuitdop de toppen van de bomen net raakte en er minimaal over de boomtoppen heen gespoten werd. 

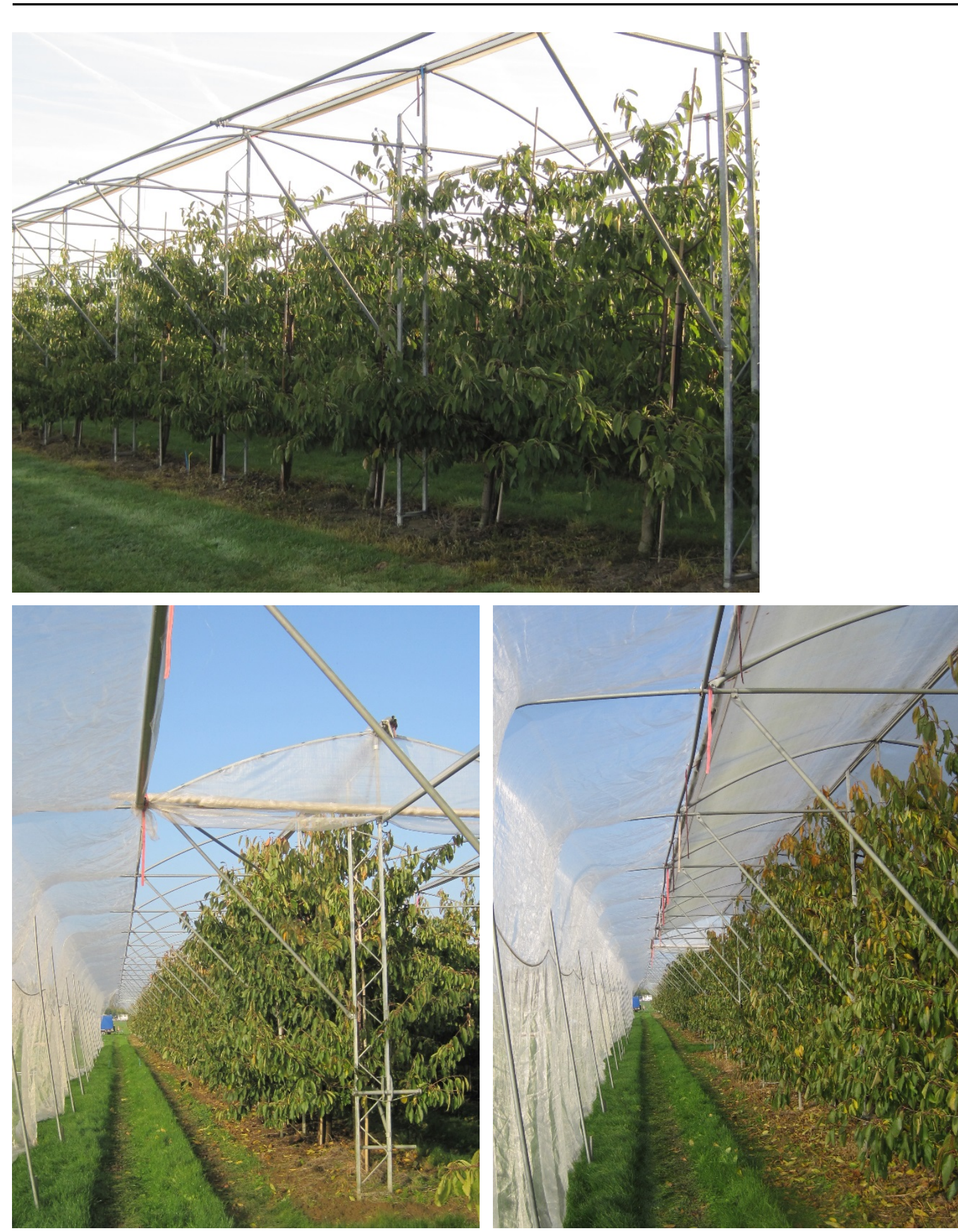

Figuur 2.2 Foto's objecten: open kap (boven), open kap met suzuki-fruitvlieggaas (onder links) en dichte regenkap met suzuki-fruitvlieggaas (onder rechts).

De drie objecten werden bespoten met twee technieken:

1. Referentie techniek; Albuz ATR-lila (=standaard dop); bij 7 bar; rijsnelheid 6,7 km/h, de buitenste bomenrij tweezijdig bespoten in de vollucht instelling (hoge ventilator stand en $540 \mathrm{rpm}$ aftakas); spuitvolume $150 \mathrm{~L} / \mathrm{ha}$.

2. 95\% driftreducerend (DRT95; TCT, 2019); TVI8001 (90\% driftreducerende dop, TCT, 2020; DRT90), bij 9 bar; rijsnelheid 6,7 km/h; buitenste bomenrij eenzijdig bespoten en de lucht in de lage ventilator stand bij 540 rpm aftakas; spuitvolume 250 I/ha.

In figuur 2.3 staan schematische weergaven van de bespuitingen met de 2 technieken. 
6 bomenrijen bespuiten

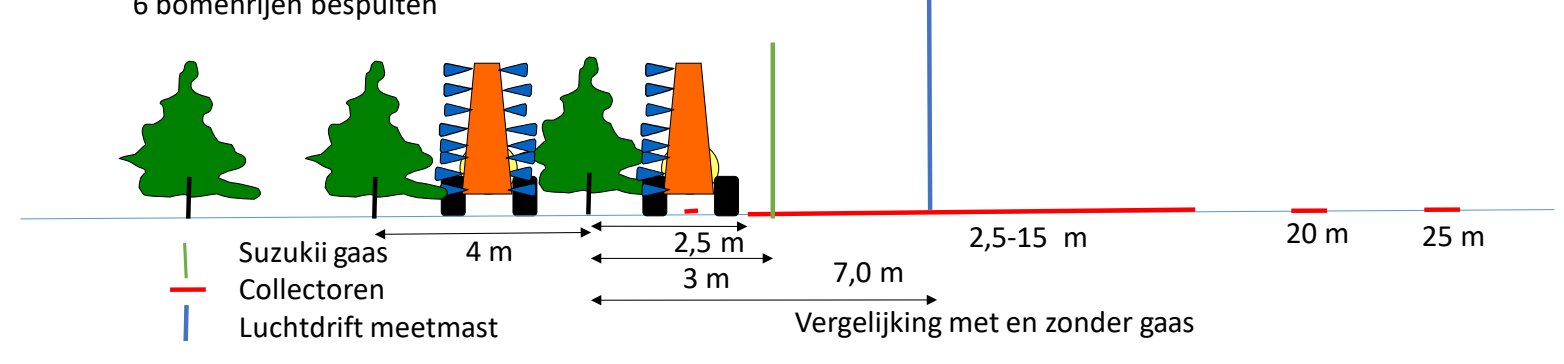

DRT95:

Eenzijdig buitenste bomenrij $90 \%$ driftreducerende dop Lage lucht instelling

6 bomenrijen bespuiten

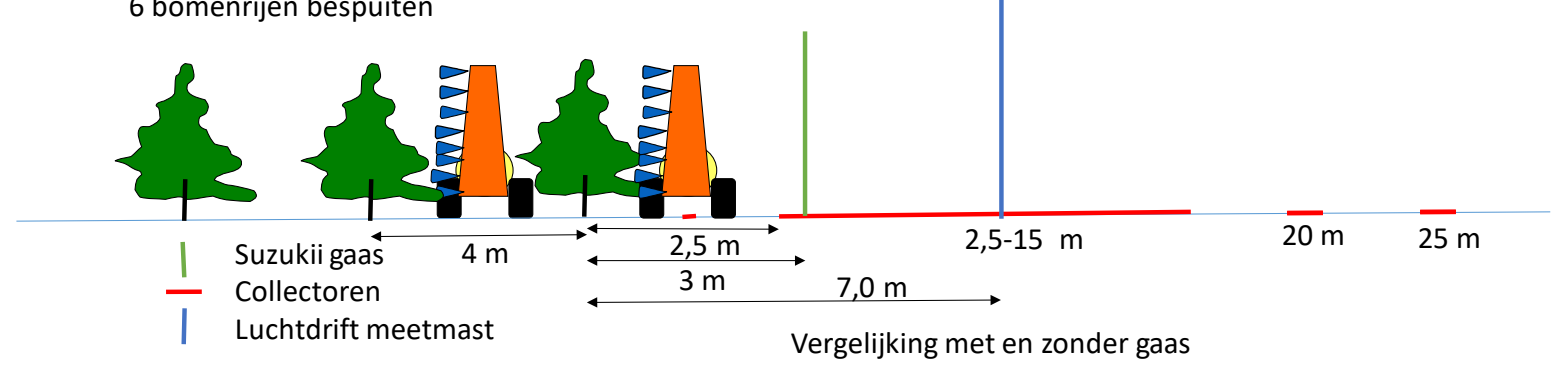

Figuur 2.3 Schematische weergave van de uitvoering bespuitingen met de standaard techniek (boven) en de driftreducerende techniek (onder).

\subsubsection{Karakteristieken Munckhof Eco kap dwarsstroom boomgaardspuit}

In tabel 2.1 staan de posities van de dophouders van de Munckhof (halfhoge, 2,40 m hoog) Eco kap dwarsstroom boomgaardspuit boven grondoppervlak weergegeven.

Tabel 2.1 Dophoogte vanaf de grond [cm] van de dophouders op de Munckhof Eco kap dwarsstroomspuit.

\begin{tabular}{lrrrrrrrr} 
Dopnr & 1 & 2 & 3 & 4 & 5 & 6 & 7 \\
Links/rechts & 46,5 & 63 & 81 & 100 & 144 & 169 & 195 & 220 \\
\hline
\end{tabular}

Er werd gespoten met $2 \times 8$ geopende spuitdoppen. De bovenste spuitende dop zat op 2,20 m hoogte. De spuit werd aangedreven door een John Deere JD 5075 GV fruitteelt trekker.

De referentietechniek met ATR Lila spuitdop (figuur 2.4) werd gespoten met een rijsnelheid van $6,7 \mathrm{~km} / \mathrm{h}$ en een aftakas toerental van $540 \mathrm{rpm}$. Er werd gemeten bij de vollucht stand van de ventilator, hierbij was de gemiddelde luchtsnelheid $25,2 \mathrm{~m} / \mathrm{s}$. Het spuitvolume was $150 \mathrm{l} / \mathrm{ha}$.

De driftreducerende techniek met TVI 8001 spuitdop (figuur 2.4) werd gespoten met een rijsnelheid van $6,7 \mathrm{~km} / \mathrm{h}$ en een aftakas toerental van $540 \mathrm{rpm}$. Er werd gemeten in de lage lucht stand van de ventilator, hierbij was de gemiddelde luchtsnelheid $21,8 \mathrm{~m} / \mathrm{s}$. Het spuitvolume was $250 \mathrm{l} / \mathrm{ha}$.

In figuur 2.5 staan foto's van de spuit tijdens de driftmetingen. 


\subsubsection{Samenvatting gebruikte spuittechnieken}

In tabel 2.2 staat een samenvatting van de tijdens de driftmetingen gebruikte spuittechnieken.

Tabel 2.2 Samenvatting gebruikte spuittechnieken in de driftmetingen.

\begin{tabular}{|c|c|c|}
\hline Spuit & Referentie & Driftreducerend \\
\hline Spuitdoppen & Albuz & Albuz \\
\hline doptype & Werveldop & Venturi werveldop \\
\hline druk [bar] & 7 & 9 \\
\hline dop afgifte $[\mathrm{l} / \mathrm{min}]$ & 0,43 & 0,69 \\
\hline rijsnelheid [km/h] & 6,7 & 6,7 \\
\hline spuitvolume [l/ha] & 150 & 250 \\
\hline Ventilatorstand & Hoog (haas) & Laag (schildpad) \\
\hline
\end{tabular}
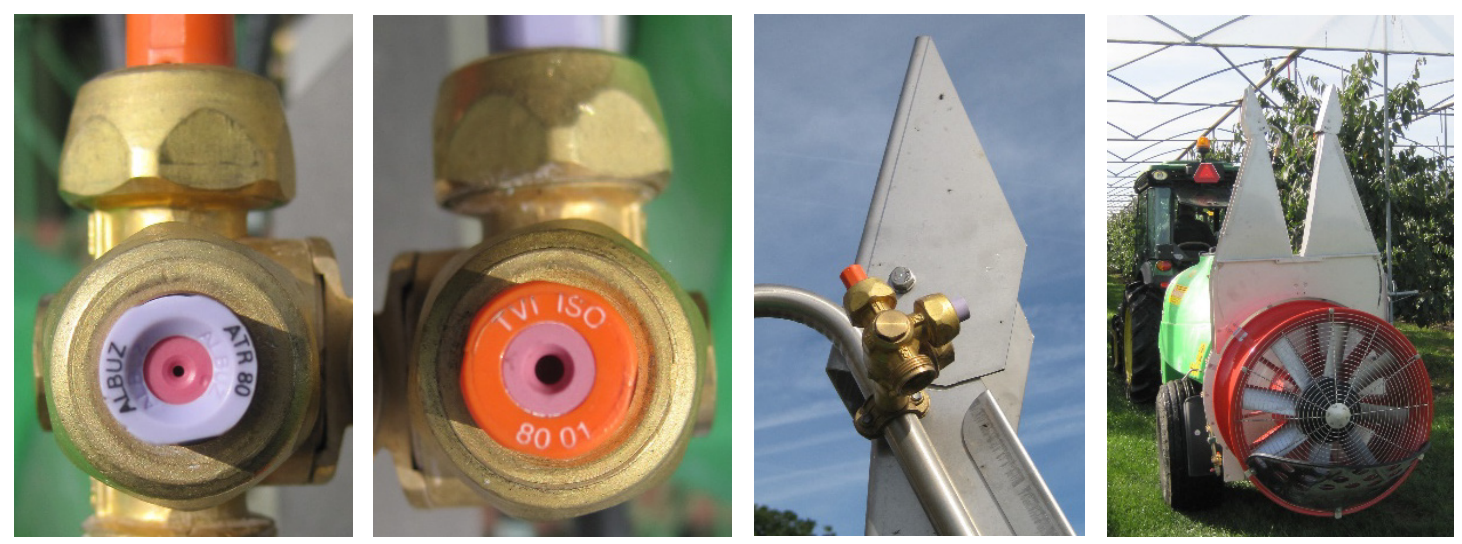

Figuur 2.4 Munckhof Eco kap dwarsstroom boomgaardspuit (rechts), klepstand luchtgeleiding bij bovenste dop (midden rechts), Albuz ATR lila (links) en TVI8001 (links midden) spuitdoppen.

Tijdens de metingen werd telkens de instelling van de spuit = doptype, spuitdruk, rijsnelheid, eenzijdig spuiten gecontroleerd en vastgelegd. 

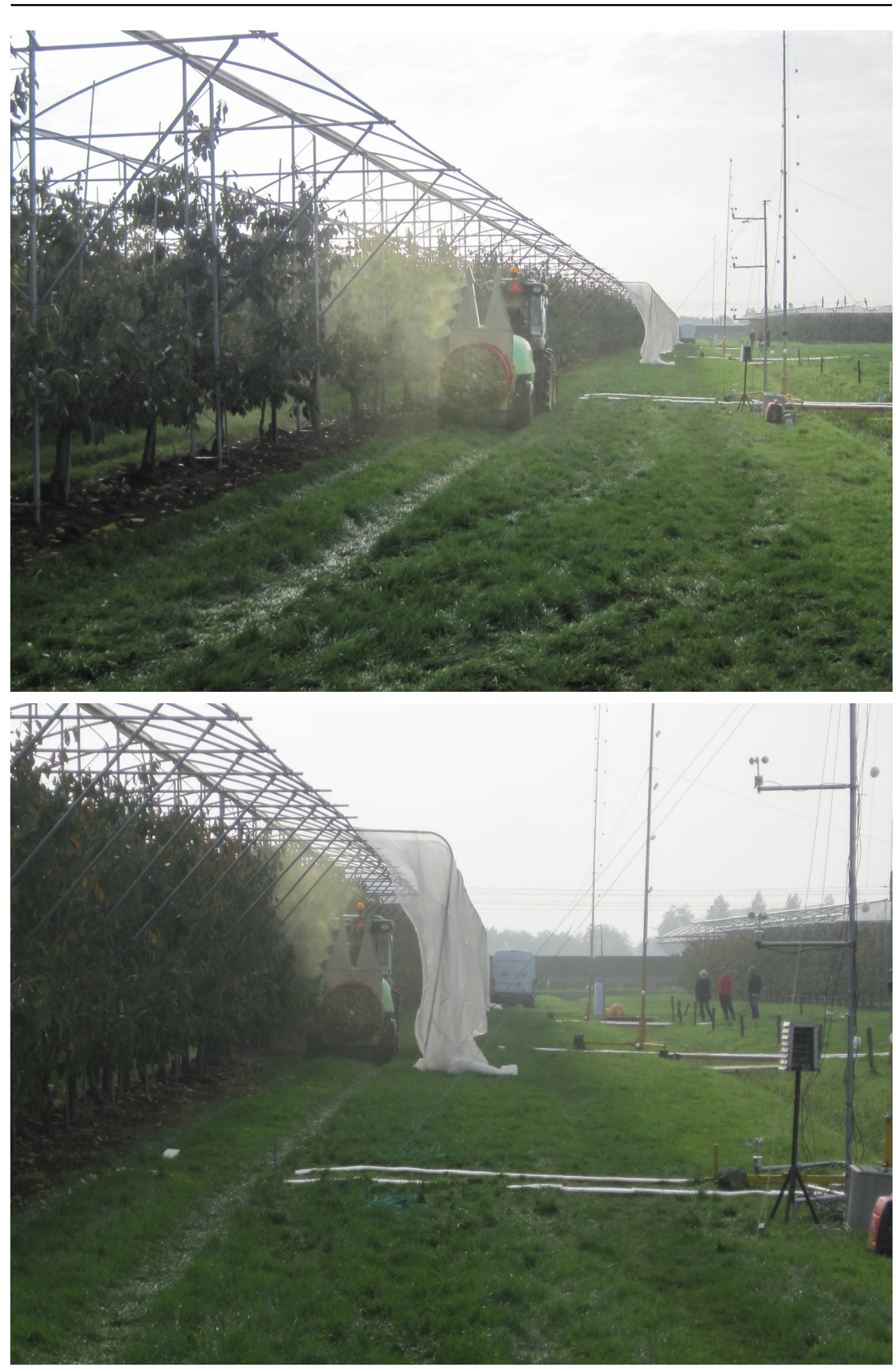

Figuur 2.5 Foto's tijdens bespuitingen met de Munckhof (halfhoge, 2,40 m hoog) Eco kap dwarsstroom boomgaardspuit. 


\subsection{Beschrijving metingen en verwerking resultaten}

\subsubsection{Metingen}

De experimenten werden op 20 september, 23 oktober en 31 oktober 2019 uitgevoerd op een perceel kersen aan de Eierkampseweg in Echteld (Noorderbreedte 51 ${ }^{\circ} 55^{\prime} 18.7^{\prime \prime}$, Oosterlengte 5³0'12.1"). De driftmetingen werden in overeenstemming met de driftmeetprotocollen (TCT 2017b, ISO22866) uitgevoerd. De kersenbomen (ras: Regina; geplant: februari 2013) staan in een plantverband van $1,80 \mathrm{~m}$ afstand in de rij en $4 \mathrm{~m}$ tussen de rijen (rijafstand). De bomen waren 3,3 $\mathrm{m}$ hoog tot de dwarsstang van de regenkapconstructie en in het volblad stadium (BBCH 90/92, met ongeveer 20\% bladval bij de laatste bespuitingen op 31 oktober 2019). Het perceel bestond uit een blok van 140 meter lengte (figuur 2.6). Het blok was ingedeeld in twee blokken van $45 \mathrm{~m}$ en een blok van $50 \mathrm{~m}$. Op de blokken van $45 \mathrm{~m}$ stonden respectievelijk de kersen met open kappen (noordzijde) en open kappen met suzuki-fruitvlieggaas (midden). Op het blok van $50 \mathrm{~m}$ (zuidzijde) stonden de kersen met dichte kappen met suzuki-fruitvlieggaas aan de buitenkant.

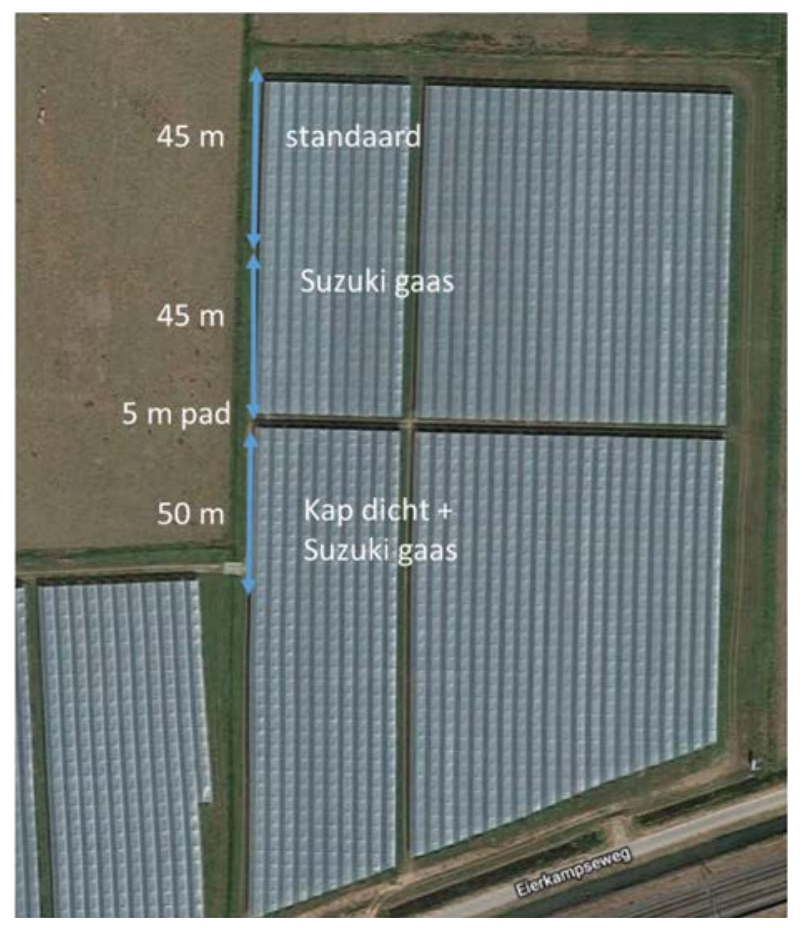

Figuur 2.6 Overzicht situatie van de drie objecten (standaard, suzuki-fruitvlieggaas, kap dicht + suzuki-fruitvlieggaas) op het perceel te Echteld (Google).

Op het perceel aan de buitenkant van de buitenste bomenrij lag een strook gras van $7 \mathrm{~m}$ breedte, een sloot van $2 \mathrm{~m}$ breed op 7-9 m en aansluitend een weiland; beiden met kortgemaaid gras. Op deze strook werden bij de drie objecten driftmeetstroken uitgelegd. Tijdens de driftmetingen werden de buitenste zes bomenrijen ( $24 \mathrm{~m}$ ) aan de benedenwindse zijde volledig bespoten. Met één en dezelfde instelling werd steeds het blok van zes boomrijen bespoten.

Bij elke driftmeetstrook werden twee meetraaien (duplo bepalingen) uitgelegd met 2 meter tussenruimte tussen de meetraaien.

Op de volgende posities werden collectoren (Technofil TF $290 ; 10 \times 100 \mathrm{~cm}, 10 \times 50 \mathrm{~cm}$ ) gelegd om de driftdepositie naar de grond te meten:

- Op 1,5 meter, evenwijdig aan de buitenste bomenrij, een collector van 1 meter lengte.

- Op 2,5 - 15 meter aaneengesloten collectoren van 0,5 meter lengte (haaks op de bomenrij).

- Op 20 en 25 meter een collector van 1 meter lengte (haaks op de bomenrij).

De afstand werd gemeten vanaf het midden (hart) van de buitenste bomenrij. 
Over de sloot is een constructie gemaakt waardoor de collectoren over de sloot op hetzelfde niveau lagen als op de grasstrook en als in de wei (figuur 2.7).

Omdat naast het perceel op 7-9 m een sloot lag werd de emissie naar de lucht op 7,0 m vanaf de laatste bomenrij gemeten met behulp van een mast van $10 \mathrm{~m}$ hoogte met daaraan in twee lijnen met op elke meter hoogte een driftbolcollector (Siral Abdriftkollektoren art. nr. 00131).

In figuur 2.7 staan foto's van de meetopstelling.
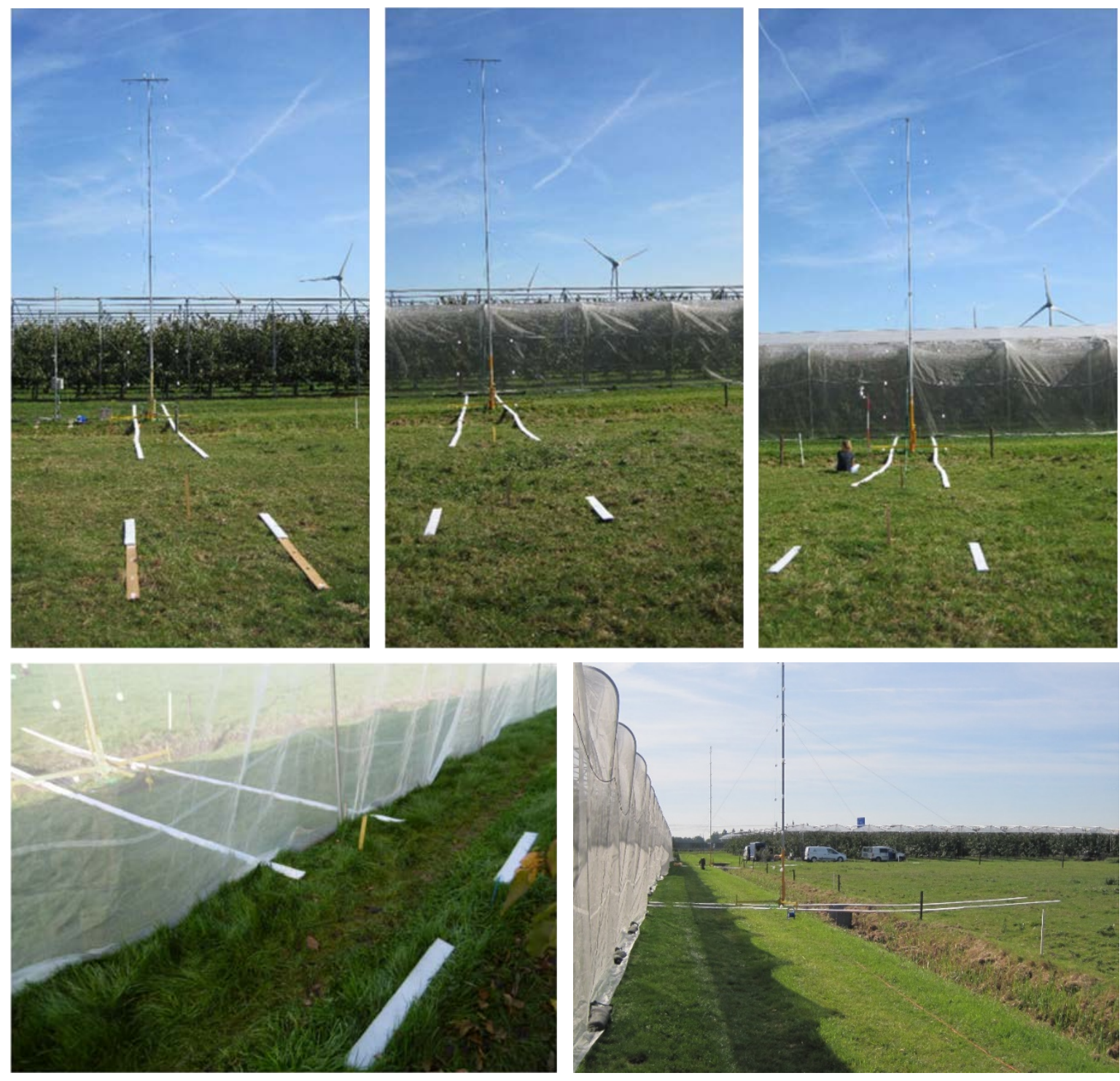

Figuur 2.7 Driftmeetopstelling bij open kap (boven links), open kap met suzuki-fruitvlieggaas (boven midden) en dichte kap met suzuki-fruitvlieggaas (boven rechts), detailopname collectoren voor en achter suzuki-fruitvlieggaas (onder links) en overzicht driftmeetopstelling met constructie over de sloot (onder rechts).

\subsubsection{Analyses}

De bespuitingen werden uitgevoerd met water waaraan Acid Yellow 250 (AY250, DC Finechemicals, CAS nummer 93859-32-6, 2-5 g/l) en een niet-ionische uitvloeier (Agral Gold, 0,075 ml/l) was toegevoegd. Na de bespuiting werden de collectoren verzameld en gecodeerd voor verdere analyse op de hoeveelheid AY250. Elke meetdag werden uit een spuitende spuitdop ook monsters van de tankvloeistof genomen om de AY250-concentratie van de verspoten spuitvloeistof te meten. In het laboratorium werden de collectoren met gedemineraliseerd water gespoeld, zodanig dat de AY250 op 
de collectoren in oplossing kwam. Van deze oplossing werd de concentratie aan AY250 gemeten met behulp van een fluorimeter (Perkin Elmer LS 55; $\lambda_{\mathrm{ex}}=450 \mathrm{~nm} ; \lambda_{\mathrm{em}}=500 \mathrm{~nm}$ ). Voor het bepalen van de achtergrondfluorescentie werden blanco collectoren geanalyseerd. De concentratie AY250 in de tankmonsters werd ook fluorimetrisch bepaald. De afbraak in zonlicht van de AY250 op de collectoren werd apart bepaald. Gezien de beperkte blootstellingsduur aan zonlicht van de collectoren tijdens de driftmetingen in het veld ( $<30$ minuten) was het niet nodig voor afbraak door zonlicht te corrigeren.

\subsubsection{Berekeningen en statistiek}

De concentratie werd omgerekend naar volume spuitvloeistof per oppervlakte-eenheid. Het percentage drift is berekend door de driftdepositie per oppervlakte-eenheid uit te drukken in procenten van de door de spuitdoppen in het perceel verspoten hoeveelheid vloeistof per oppervlakte-eenheid.

De gemeten fluorescentiewaarde werd omgerekend naar de driftdepositie $\left(\mu \mathrm{l} / \mathrm{cm}^{2}\right)$ volgens:

$$
\begin{array}{ll}
D_{\text {monster }}= & \frac{\left(F_{\text {monster }}-F_{\text {demi }}-F_{\text {blanco }}\right) \times f_{i j k} \times V_{\text {spoel }}}{C_{\text {tm }} \times A_{\text {monster }}} \\
\mathrm{D} & =\text { depositie in } \mu \mathrm{L} / \mathrm{cm}^{2} ; \\
\mathrm{F} & =\text { fluorescentiewaarde; } \\
\mathrm{F}_{\text {monster }} & =\text { fluorescentiewaarde van het monster; } \\
\mathrm{F}_{\text {demi }} & =\text { fluorescentiewaarde van demiwater; } \\
\mathrm{F}_{\text {blanco }} & =\text { bijdrage van de achtergrond door collector; } \\
\mathrm{f}_{\mathrm{ijk}} & =\text { ijkfactor; } \\
\mathrm{V}_{\text {spoel }} & =\text { extractievolume in liter; } \\
\mathrm{C}_{\mathrm{tm}} & =\text { spuitvloeistofconcentratie in tank in } \mathrm{g.L} \mathrm{L}^{-1} ; \\
\mathrm{A}_{\text {monster }} & =\text { monsteroppervlak in } \mathrm{cm}^{2} .
\end{array}
$$

Voor de statistische verwerking wordt indien $\left(F_{\text {monster }}-F_{\text {demi }}-F_{\text {blanco }}\right)$ kleiner of gelijk aan 0 is, hier een kleine waarde ingevuld $(0,001)$.

Vervolgens werd per monster de driftdepositie uitgedrukt als percentage van het uitgebracht spuitvolume volgens:

$$
P=\frac{D_{m}}{Q / 100} \times 100 \%
$$

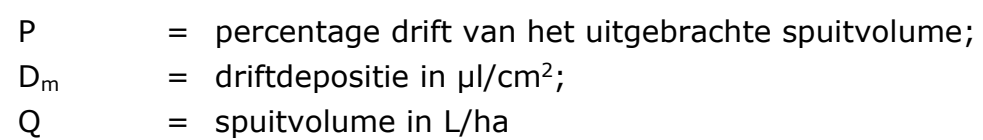

Voor de vergelijking van de driftdepositie van de verschillende spuittechnieken zijn de driftwaarden (\% van spuitvolume) uitgerekend voor verschillende evaluatiestroken overeenkomend met de positie van de sloot (insteek-insteek afstand $4 \mathrm{~m}$ ) en het wateroppervlak daarbinnen $(1 \mathrm{~m})$. De teeltvrije zone wordt in het Activiteitenbesluit Milieubeheer (I\&W, 2017) gedefinieerd als de afstand tussen de insteek van de sloot en de buitenste gewasrij (voor fruitteelt $3 \mathrm{~m}$ in figuur 2.8). De volgende evaluatiestroken worden onderscheiden:

- slootoppervlak: 3-7 m en 41/2-81/2 m, bij respectievelijk $3 \mathrm{~m}$ en $41 \frac{1}{2} \mathrm{~m}$ teeltvrije zone.

- wateroppervlak: 41/2-51/2 en 6-7 m, bij respectievelijk 3 en $41 / 2 \mathrm{~m}$ teeltvrije zone.

- Voor de bespuiting van de kersen, die geplant zijn op een rijafstand van $4 \mathrm{~m}$, is de standaard teeltvrije zone overeenkomstig de rijafstand van de bomen minimaal $4 \mathrm{~m}$. Dit houdt in dat de evaluatiezone voor niet-doelwit arthropoden en planten op 3,5-4,5 $\mathrm{m}$ van de laatste bomenrij ligt (0,50-1,50 m achter het gaas dat op 3,0 m stond).

- Voor de bespuiting van de kersen, die geplant zijn op een rijafstand van $4 \mathrm{~m}$, is de standaard teeltvrije zone overeenkomstig de rijafstand minimaal $4 \mathrm{~m}$. Dit houdt in dat de evaluatiezone voor wateroppervlak op 5,5-6,5 $\mathrm{m}$ van de laatste bomenrij ligt.

- naar de lucht: gemiddeld over $10 \mathrm{~m}$ hoogte op 7,0 m vanaf de laatste bomenrij. 


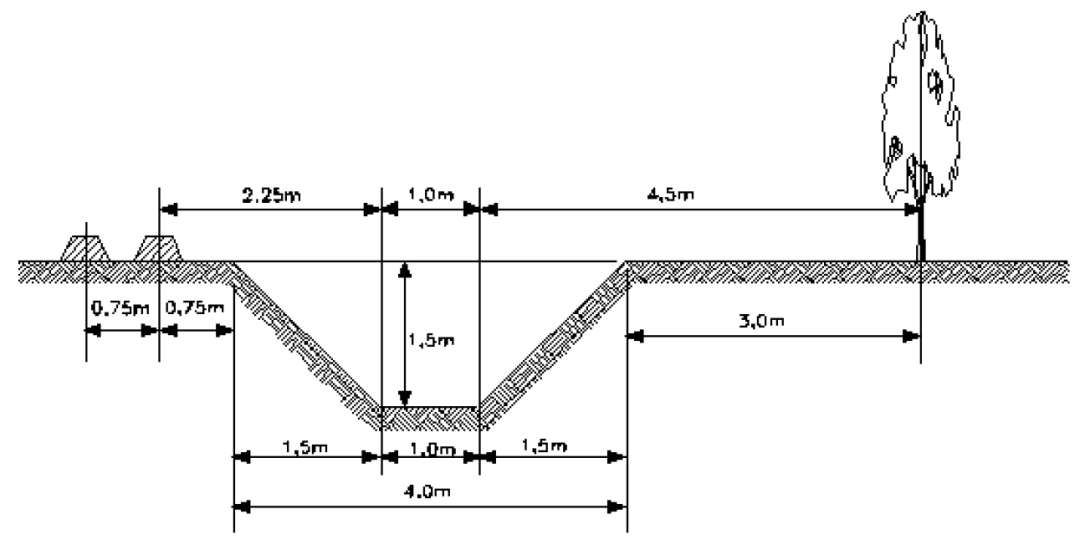

Figuur 2.8 Schematische weergave van de plaats van de sloot, het talud en het wateroppervlak ten opzichte van de laatste gewasrij in aardappelen (links) en de buitenste bomenrij in de fruitteelt (rechts) (Huijsmans et al., 1997).

De gekozen zones van $3 \mathrm{~m}$ en $4 \frac{1}{2} \mathrm{~m}$, komen overeen met de in het Activiteitenbesluit Milieubeheer (I\&W, 2017) genoemde zones voor de fruitteelt. Daarbij is 4,5 $\mathrm{m}$ de teeltvrije zone waarbij een bespuiting nog met een $75 \%$ driftreducerende spuittechniek (DRT75) uitgevoerd mag worden. De zone $3 \mathrm{~m}$ geldt als teeltvrije zone als de bespuiting uitgevoerd wordt met een $90 \%$ driftreducerende techniek (DRT90).

De verschillen in driftdepositiewaarden op de evaluatiestroken tussen de verschillende spuittechnieken werden getoetst bij een onbetrouwbaarheidsdrempel van $5 \%$. Statistische analyse vond plaats met behulp van het statistische programma Genstat (Genstat Release 20, VSN International, 2019). Bij de statistische analyse werd gebruik gemaakt van de Genstat procedure IRREML (Keen en Engel, 1998). In Bijlage 1 staat het gebruikte IRREML script.

Voor de indeling van de verschillende combinaties (kapconstructie/doptype) in driftreductieklassen werd de driftreductie op de gemeten afstanden en de evaluatiestroken berekend ten opzichte van de driftdepositie van de referentie bespuiting met de Munckhof ECO kap dwarsstroom boomgaardspuit uitgerust met Albuz ATR Lila doppen bij open kappen volgens:

$\%$ reductie $=\frac{\left(P_{\text {driftref }}-P_{\text {techniek }}\right)}{P_{\text {driftref }}} \times 100 \%$

$\mathrm{P}_{\text {driftref }} \quad=$ Percentage drift referentietechniek: Standaard dwarsstroomspuit (Munckhof ECO kap) met ATR lila werveldoppen in de situatie met open kappen.

$\mathrm{P}_{\text {techniek }}=$ Percentage drift spuittechniek met ATR lila werveldoppen en met TVI8001 spuitdoppen ( $90 \%$ driftreducerende dop), lage luchtinstelling en eenzijdig spuiten van de buitenste bomenrij (DRT95) in combinatie met de verschillende constructies (open kap, open kap met suzuki-fruitvlieggaas en dichte kap met suzuki-fruitvlieggaas).

De indeling in driftreductieklasse op de strook 4,5-5,5 $\mathrm{m}$ van de laatste bomenrij geldt hierbij als de indeling in Drift Reducerende Techniek (DRT) klasse (TCT2017a, 2017b).

Voor het bepalen van de achtergrondfluorescentie werden blanco collectoren geanalyseerd. Het resultaat van deze metingen is een gemiddelde achtergrondfluorescentie van de blanco collectoren met een bijbehorende standaardafwijking. Bij de berekeningen van de driftdepositie (volgens bovenstaande formules) wordt het gemiddelde van de achtergrondfluorescentie gebruikt. Bij een paar experimenten werden zeer lage driftdeposities gemeten met fluorescentiewaarden dicht of zelfs onder de gemiddelde achtergrondfluorescentie. Berekende driftdeposities kunnen dan zelfs lager dan 0\% worden. De drempelwaarde, in dit rapport aangehouden, is de gemiddelde fluorescentiewaarde van de blanco plus 
twee keer de standaardafwijking van de blanco. Deze drempelwaarde is omgerekend naar driftdepositie volgens bovenstaande formules. De drempelwaarde is o.a. afhankelijk van de gemeten techniek (spuitvolume), spoelvolume bij de extractie, collectorgrootte en tankconcentratie en kan per meting (herhaling) verschillen. In de bijlagen staan de berekende waarden, ook die onder de drempelwaarde vallen. Getallen die onder de bijbehorende drempelwaarde vallen staan cursief. Als er in het rapport zelf getallen gepresenteerd worden (bv in samenvattende tabel met de afstand) waarbij de gemiddelde gemeten waarde onder de drempelwaarde komt dan wordt dat aangeven met '<drempelwaarde'. Bijvoorbeeld '<0,005'. Bij deze experimenten liggen de gemiddelde gemeten waarden steeds boven de drempelwaarde.

\subsection{Weersomstandigheden}

Tijdens de bespuitingen werden de weersomstandigheden vastgelegd door meting van de temperatuur (Pt100 op 0,5 m en 4 m hoogte), de luchtvochtigheid (\% RV met een Rhotronic op 1,5 m hoogte), de windrichting $\left(0^{\circ}=\right.$ haaks t.o.v. de bomenrijen) op $10 \mathrm{~m}$ hoogte en de windsnelheid (cupanemometers op $0,5,2,3,4$ en 10 m hoogte) met een tijdsinterval van 5 seconden.

De meteomast stond op 7,0 m afstand vanaf de buitenste bomenrij. Bij elke passage van de spuit ter hoogte de meetopstellingen werd de tijd van de datalogger genoteerd. Later werd uit de verzamelde data vanuit dit passagetijdstip over 10 seconden vóór en 10 seconden ná passeertijdstip de meetwaarde gemiddeld. In Bijlage 2 staan de resultaten van de metingen van de weersomstandigheden vermeld.

De metingen werden in 2019 uitgevoerd op 20 september, 23 oktober en 31 oktober. In totaal werden 8 herhalingen gemeten. Bij één van de acht herhaling met de ATR Lila dop bij open kappen (\#1) en één herhaling van de ATR Lila doppen in combinatie met dichte kap+gaas (\#1) week de gemiddelde windhoek te veel af van haaks. Deze metingen zijn niet verwerkt in de resultaten. Bij deze twee combinaties zijn de drift resultaten gebaseerd op 7 herhalingen, bij de overige combinaties op 8 herhalingen. De gemiddelde weersomstandigheden van alle metingen staan in tabel 2.3.

Tabel 2.3 Gemiddelde weersomstandigheden voor de verschillende objecten tijdens de driftmetingen in 2019 (8 herhalingen).

\begin{tabular}{|c|c|c|c|c|c|c|c|c|c|c|}
\hline \multirow[t]{2}{*}{ Constructie } & \multirow[t]{2}{*}{ Spuittechniek } & \multicolumn{2}{|c|}{$\begin{array}{c}\text { Temperatuur } \\
{\left[{ }^{\circ} \mathrm{C}\right] \text { op }} \\
\end{array}$} & \multirow[t]{2}{*}{$\%$ RV } & \multirow{2}{*}{$\begin{array}{l}\text { Windhoek } \\
\text { tov haaks } \\
\text { haaks }=0^{\circ}\end{array}$} & \multicolumn{5}{|c|}{ Windsnelheid [m/s] op } \\
\hline & & $0,5 \mathrm{~m}$ & $4 \mathrm{~m}$ & & & $0,5 \mathrm{~m}$ & $2 \mathrm{~m}$ & $3 \mathrm{~m}$ & $4 m$ & $10 \mathrm{~m}$ \\
\hline Open kap & TVI 8001 & 15,8 & 14,5 & 56 & -11 & 0,7 & 1,0 & 1,1 & 2,0 & 3,5 \\
\hline Open kap met gaas & ATR Lila & 15,9 & 14,5 & 57 & -10 & 0,7 & 1,1 & 1,4 & 2,0 & 3,8 \\
\hline \multirow[t]{2}{*}{ Dichte kap met gaas } & ATR Lila & 15,9 & 14,4 & 57 & -11 & 0,8 & 1,2 & 1,5 & 2,3 & 4,0 \\
\hline & TVI 8001 & 15,9 & 14,5 & 56 & -9 & 0,7 & 1,0 & 1,2 & 2,1 & 3,5 \\
\hline
\end{tabular}

Tijdens de driftmetingen was de gemiddelde temperatuur $14,5^{\circ} \mathrm{C}$ (op $4 \mathrm{~m}$ hoogte), de gemiddelde windhoek $-11^{\circ}$ ten opzichte van loodrecht op de bomenrij en de gemiddelde windsnelheid op $2 \mathrm{~m}$ hoogte $1,0 \mathrm{~m} / \mathrm{s}$ en op $4 \mathrm{~m}$ hoogte (ongeveer $1 \mathrm{~m}$ boven de bomen) $2,1 \mathrm{~m} / \mathrm{s}$. 


\section{Resultaten}

De resultaten van de metingen van de drift naar de grond naast het perceel zijn weergegeven in Bijlage 3 en de resultaten van de drift naar de lucht zijn weergegeven in Bijlage 4.

\subsection{Drift naar de grond naast het perceel}

De gemiddelde drift per spuittechniek (ATR/TVI) in combinatie met verschillende constructies (Open kap/ Open kap met suzuki-fruitvlieggaas/ Dichte kap met suzuki-fruitvlieggaas) tijdens bespuitingen in de volblad situatie staat weergegeven in figuur 3.1 en in tabel 3.1.

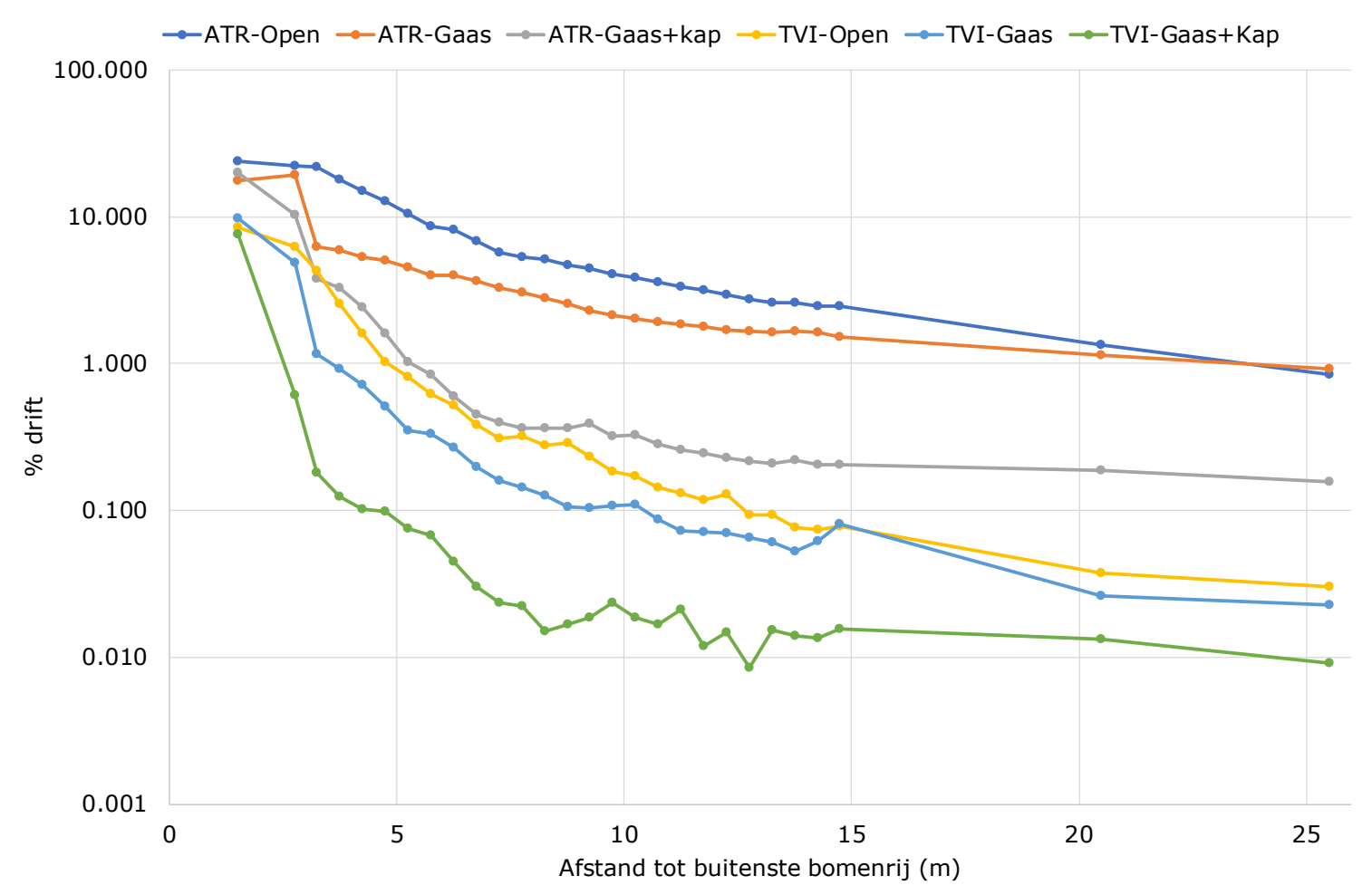

Figuur 3.1 Gemiddelde drift (\% van verspoten hoeveelheid spuitvloeistof per oppervlakte-eenheid) op verschillende afstanden vanaf het hart van de buitenste bomenrij bij bespuitingen van een kersenperceel met 3 constructies (Open kap, Open kap met suzuki-fruitvlieggaas, Dichte kap met suzuki-fruitvlieggaas) met een standaard dwarsstroomspuit (Munckhof ECO kap) met ATR lila werveldoppen en met TVI8001 spuitdoppen (90\% driftreducerende dop), lage luchtinstelling en eenzijdig spuiten van de buitenste bomenrij (DRT95).

In figuur 3.1 en tabel 3.1 is te zien dat bij de 3 constructies (Open kap, Open kap met suzukifruitvlieggaas, Dichte kap met suzuki-fruitvlieggaas) de standaard bespuiting (Munckhof ECO kap) met ATR Lila werveldoppen de meeste drift geeft. Bespuitingen met TVI8001 spuitdoppen (90\% driftreducerende dop, lage luchtinstelling en eenzijdig spuiten van de buitenste bomenrij; DRT95) geven onafhankelijk van de constructie de laagste drift. Ook is te zien dat bij de twee spuittechnieken de drift bij de open kap steeds het hoogst is gevolgd door de drift met de open kap met suzukifruitvlieggaas. De dichte kap met suzuki-fruitvlieggaas geeft steeds de laagste drift. Dit is verder uitgewerkt in tabel 3.2 voor de verschillende evaluatiestroken. 
Tabel 3.1 Gemiddelde drift (\% van verspoten hoeveelheid spuitvloeistof per oppervlakte-eenheid) op verschillende afstanden vanaf het hart van de buitenste bomenrij bij bespuitingen van een kersenperceel met 3 constructies (Open kap, Open kap met suzuki gaas, Dichte kap met suzuki gaas) met een standaard dwarsstroomspuit (Munckhof ECO kap) met ATR lila werveldoppen en met TVI8001 spuitdoppen (90\% driftreducerende dop), lage luchtinstelling en eenzijdig spuiten van de buitenste bomenrij (DRT95).

\begin{tabular}{|c|c|c|c|c|c|c|}
\hline \multirow{2}{*}{$\begin{array}{l}\text { Afstand tot buitenste } \\
\text { bomenrij (m) }\end{array}$} & \multicolumn{2}{|c|}{ Open Kap } & \multicolumn{2}{|c|}{ Open kap+suzuki gaas } & \multicolumn{2}{|c|}{ Dichte kap+suzuki gaas } \\
\hline & ATR & TVI & ATR & TVI & ATR & TVI \\
\hline $25-26$ & 0,848 & 0,030 & 0,926 & 0,023 & 0,156 & 0,009 \\
\hline $14 \frac{1}{2}-15$ & 2,477 & 0,078 & 1,511 & 0,081 & 0,206 & 0,016 \\
\hline $14-14 \frac{1}{2}$ & 2,466 & 0,074 & 1,635 & 0,062 & 0,204 & 0,013 \\
\hline $13-13 \frac{1}{2}$ & 2,620 & 0,094 & 1,627 & 0,060 & 0,210 & 0,015 \\
\hline $12 \frac{1}{2}-13$ & 2,747 & 0,093 & 1,656 & 0,066 & 0,217 & 0,009 \\
\hline $12-12 \frac{1}{2}$ & 2,925 & 0,128 & 1,707 & 0,070 & 0,228 & 0,015 \\
\hline $11 \frac{1}{2}-12$ & 3,144 & 0,118 & 1,775 & 0,071 & 0,246 & 0,012 \\
\hline $91 / 2-10$ & 4,065 & 0,183 & 2,129 & 0,107 & 0,321 & 0,023 \\
\hline $9-91 / 2$ & 4,435 & 0,232 & 2,315 & 0,104 & 0,390 & 0,019 \\
\hline $81 / 2-9$ & 4,691 & 0,289 & 2,539 & 0,106 & 0,365 & 0,017 \\
\hline $8-81 / 2$ & 5,137 & 0,279 & 2,818 & 0,126 & 0,362 & 0,015 \\
\hline $71 / 2-8$ & 5,313 & 0,323 & 3,082 & 0,144 & 0,365 & 0,022 \\
\hline $7-71 / 2$ & 5,744 & 0,311 & 3,287 & 0,161 & 0,399 & 0,023 \\
\hline $61 / 2-7$ & 6,850 & 0,383 & 3,633 & 0,197 & 0,452 & 0,030 \\
\hline $6-61 / 2$ & 8,182 & 0,518 & 4,020 & 0,269 & 0,603 & 0,045 \\
\hline $51 / 2-6$ & 8,670 & 0,620 & 3,980 & 0,333 & 0,846 & 0,067 \\
\hline $21 / 2-3^{*}$ & 22,364 & 6,243 & 19,297 & 4,881 & 10,403 & 0,610 \\
\hline 1,5 & 23,849 & 8,551 & 17,533 & 9,852 & 19,920 & 7,636 \\
\hline
\end{tabular}

${ }^{*}=$ gaas stond tussen de collectoren $2 \frac{1}{2}-3 \mathrm{~m}$ en $3-3 \frac{1}{2} \mathrm{~m}$

Op alle stroken wordt bij de bespuitingen zonder gaas (Open kap) de hoogste drift gevonden. De drift bij gebruik van suzuki-fruitvlieggaas is significant lager. Bij gebruik van suzuki-fruitvlieggaas in combinatie met een dichte regenkap wordt significant de laagste drift gevonden. Bij alle constructies zijn de bespuitingen met TVI8001 spuitdoppen, lage luchtinstelling en eenzijdig spuiten van de buitenste bomenrij steeds significant lager dan de bespuitingen met ATR lila spuitdoppen.

Op de strook 41/2-51/2m (standaard evaluatie zone voor DRT-indeling) zijn de driftpercentages voor de drie constructies (Open kap, Open kap met suzuki gaas, Dichte kap met suzuki gaas) bij de ATR Lila spuitdoppen respectievelijk $11,6 \%, 4,8 \%$ en $1,3 \%$. De driftpercentages bij de TVI8001 spuitdoppen, lage luchtinstelling en eenzijdig spuiten van de buitenste bomenrij zijn voor de drie constructies respectievelijk $0,92 \%, 0,43 \%$ en $0,09 \%$. 
Tabel 3.2 Gemiddelde drift (\% van verspoten hoeveelheid spuitvloeistof per oppervlakte-eenheid) op de evaluatiestroken 31/2-41/2 m en 51/2-61/2 en de stroken overeenkomend met teeltvrije zones van 3 $m, 41 / 2 m, 6 m$ en $9 m$ bij bespuitingen van een kersenperceel met 3 constructies (Open kap, Open kap met suzuki gaas, Dichte kap met suzuki gaas) met een standaard dwarsstroomspuit (Munckhof ECO kap) met ATR lila werveldoppen en met TVI8001 spuitdoppen (90\% driftreducerende dop), lage luchtinstelling en eenzijdig spuiten van de buitenste bomenrij (DRT95).

\begin{tabular}{|c|c|c|c|c|c|c|}
\hline $\begin{array}{l}\text { Afstand tot buitenste } \\
\text { bomenrij ( } \mathrm{m})\end{array}$ & \multicolumn{2}{|c|}{ Open Kap } & \multicolumn{2}{|c|}{ Open kap+suzuki gaas } & \multicolumn{2}{|c|}{ Dichte kap+suzuki gaas } \\
\hline $31 / 2-41 / 2$ & 16,5 & 2,1 & 5,6 & 0,81 & 2,8 & 0,11 \\
\hline \multirow[t]{2}{*}{$51 / 2-61 / 2$} & 8,4 & 0,57 & 4,0 & 0,30 & 0,72 & 0,06 \\
\hline & $\mathrm{a}$ & $\mathrm{C}$ & $\mathrm{b}$ & d & C & $\mathrm{e}$ \\
\hline $3-7$ & a & C & $\mathrm{b}$ & d & $\mathrm{C}$ & $\mathrm{e}$ \\
\hline \multirow[t]{2}{*}{$41 / 2-51 / 2$} & 11,6 & 0,92 & 4,8 & 0,43 & 1,3 & 0,09 \\
\hline & a & C & $\mathrm{b}$ & d & c & e \\
\hline $41 / 2-81 / 2$ & 7,9 & 0,53 & 3,8 & 0,26 & 0,71 & 0,05 \\
\hline \multirow[t]{2}{*}{$6-10$} & 5,6 & 0,31 & 3,0 & 0,15 & 0,41 & 0,02 \\
\hline & $\mathrm{a}$ & C & $\mathrm{b}$ & d & C & e \\
\hline \multirow[t]{2}{*}{$71 / 2-81 / 2$} & 5,2 & 0,30 & 3,0 & 0,13 & 0,36 & 0,02 \\
\hline & $a$ & c & $\mathrm{b}$ & $d$ & c & e \\
\hline \multirow[t]{2}{*}{$9-13$} & 3,5 & 0,15 & 1,9 & 0,09 & 0,28 & 0,02 \\
\hline & $a$ & d & $\mathrm{b}$ & d & C & e \\
\hline \multirow[t]{2}{*}{$101 / 2-11 \frac{1}{2}$} & 3,4 & 0,14 & 1,9 & 0,08 & 0,27 & 0,02 \\
\hline & $\mathrm{a}$ & d & $b$ & d & c & e \\
\hline
\end{tabular}

Verschillende letters in een rij duiden op significante verschillen $(a<0,05)$ 


\subsection{Drift naar de lucht}

De gemiddelde drift naar de lucht voor de verschillende spuittechnieken zijn weergegeven in figuur 3.2 en 3.3 en in tabel 3.3 .

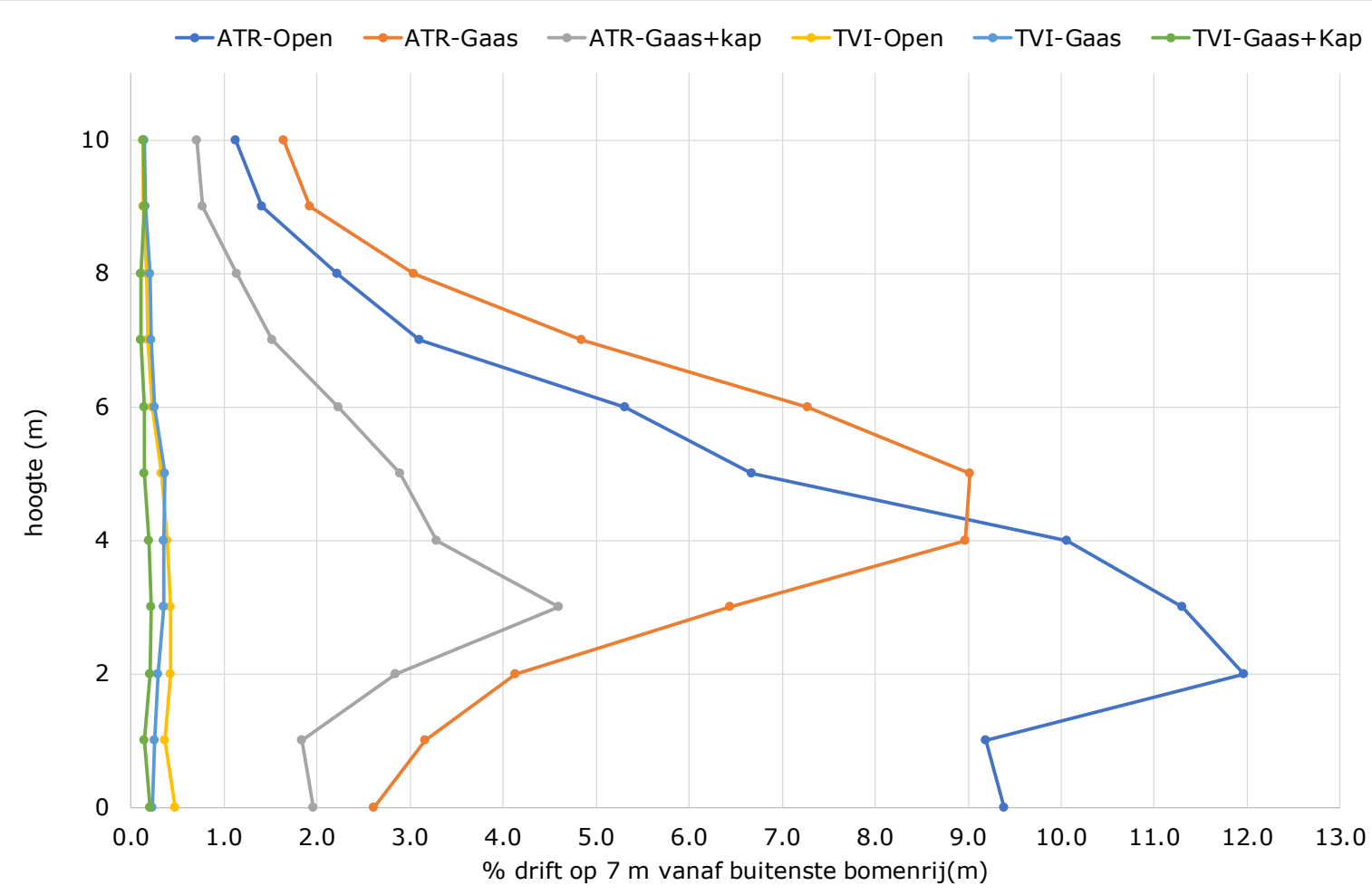

Figuur 3.2 Gemiddelde drift naar de lucht (\% van verspoten hoeveelheid spuitvloeistof per oppervlakte-eenheid) op verschillende hoogtes op $7 \mathrm{~m}$ vanaf het hart van de buitenste bomenrij bij bespuitingen van een kersenperceel met 3 constructies (Open kap, Open kap met suzukifruitvlieggaas, Dichte kap met suzuki-fruitvlieggaas) met een standaard dwarsstroomspuit (Munckhof ECO kap) met ATR lila werveldoppen en met TVI8001 spuitdoppen (90\% driftreducerende dop), lage luchtinstelling en eenzijdig spuiten van de buitenste bomenrij (DRT95).

In figuur 3.2 en in tabel 3.3 is te zien dat de hoogste drift wordt gevonden bij de bespuiting met de ATR Lila dop in de open situatie (standaardbespuiting). De maximale drift wordt daarbij gevonden op $2 \mathrm{~m}$ hoogte. Tot $4 \mathrm{~m}$ hoogte is de drift bij gebruik van suzuki-fruitvlieggaas lager dan bij de standaardbespuiting. Door het suzuki-fruitvlieggaas wordt de spuitvloeistof omhoog gestuwd waardoor de drift vanaf $4 \mathrm{~m}$ hoogte hoger is dan bij de standaard. Door het opstuwende effect wordt de maximale drift naar de lucht bij het suzuki-fruitvlieggaas gevonden op $5 \mathrm{~m}$ hoogte. Door ook gebruik te maken van een dichte kap is de drift bij de bespuitingen met ATR doppen in die situatie het laagst. Het opstuwende effect van het suzuki-fruitvlieggaas wordt door de dichte kap gedeeltelijk gecompenseerd. De hoogste drift wordt bij de situatie met suzuki-fruitvlieggaas en dichte kap gevonden op $3 \mathrm{~m}$ hoogte.

De drift bij gebruik van de TVI8001 doppen is bij alle objecten veel lager dan bij de ATR Lila spuitdoppen. De volgorde van hoogste drift naar de laagste drift is hetzelfde als bij de ATR lila doppen: TVI8001 in de open situatie is het hoogst en TVI8001 gecombineerd met suzukifruitvlieggaas en dichte kappen het laagst. Om te kijken of het opstuwende effect van het gaas ook bij TVI8001 plaats vond staan in figuur 3.3 alleen de resultaten van de drift naar de lucht voor de bespuitingen met de TVI8001 spuitdoppen. 


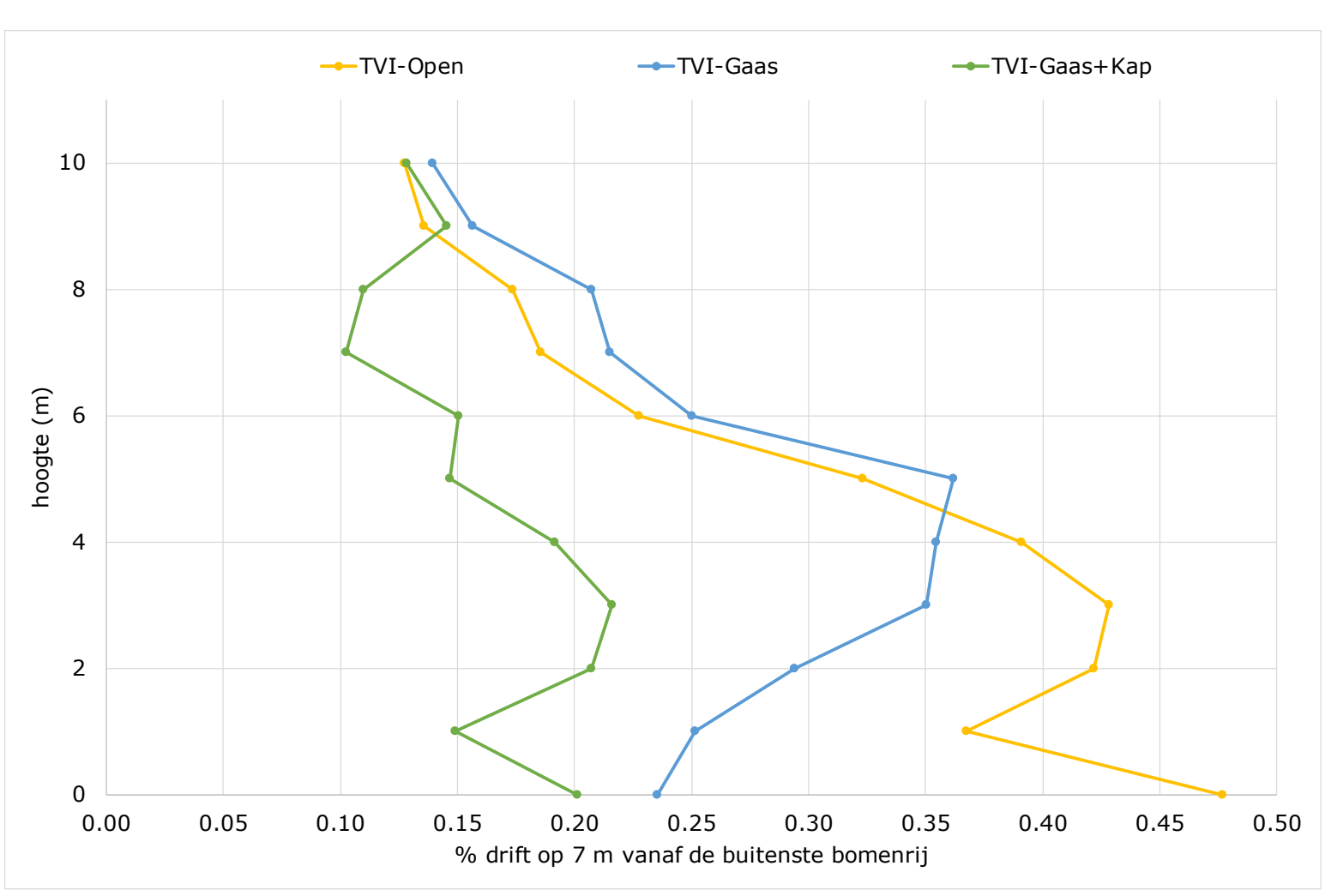

Figuur 3.3 Gemiddelde drift naar de lucht (\% van verspoten hoeveelheid spuitvloeistof per oppervlakte-eenheid) op verschillende hoogtes op $7 \mathrm{~m}$ vanaf het hart van de buitenste bomenrij bij bespuitingen van een kersenperceel met 3 constructies (Open kap, Open kap met suzukifruitvlieggaas, Dichte kap met suzuki-fruitvlieggaas) met TVI8001 spuitdoppen (90\% driftreducerende dop), lage luchtinstelling en eenzijdig spuiten van de buitenste bomenrij (DRT95).

In figuur 3.3 is te zien dat het opstuwende effect bij de TVI8001 dop hetzelfde is als bij de bespuitingen met de ATR lila doppen (figuur 3.2). Bij de TVI8001 in de open situatie wordt de hoogste drift gevonden op $3 \mathrm{~m}$ hoogte. Tot $4 \mathrm{~m}$ hoogte is de drift bij gebruik van suzuki-fruitvlieggaas lager dan de TVI8001 in de open situatie. De hoogste drift wordt gevonden op $5 \mathrm{~m}$ hoogte. Door naast het suzuki-fruitvlieggaas ook gebruik te maken van een dichte kap is de drift bij de bespuitingen daar het laagst. Het opstuwende effect van het suzuki-fruitvlieggaas wordt door de dichte kap ook bij de TVI8001 gedeeltelijk gecompenseerd. De hoogste drift wordt nu gevonden op $3 \mathrm{~m}$ hoogte.

Bij de bespuitingen met de ATR lila spuitdop worden in de situaties met open kap, open kap met suzuki-fruitvlieggaas en dichte kap met suzuki-fruitvlieggaas op $10 \mathrm{~m}$ hoogte driftdeposities van $1,2 \%, 1,6 \%$ en $0,7 \%$ gevonden. Alhoewel dit hoge waarden zijn is dit toch minder dan $10 \%$ van wat op de totale meethoogte (0-10 m) opgevangen wordt (resp. 1,6\%, 3,1\% en 3,0\%). Ook bij de TVI8001 spuitdop zijn de driftdeposities gemeten op de hoogste collector $(10 \mathrm{~m})$ voor de verschillende situaties lager dan $10 \%$ van de totale som aan depositie over de totale meethoogte $(0-10 \mathrm{~m})$; resp. $3,9 \%, 5,0 \%$ en $7,3 \%$. Dit betekent dat bij alle combinaties hoog genoeg gemeten is waardoor op het hoogste meetpunt $(10 \mathrm{~m})$ minder dan $10 \%$ van de totaal opgevangen drift naar de lucht $(0-10 \mathrm{~m})$ is opgevangen (ISO22866).

De resultaten van de driftmetingen naar de lucht zijn voor de verschillende hoogtezones verder uitgewerkt in tabel 3.4. 
Tabel 3.3 Gemiddelde drift naar de lucht (\% van verspoten hoeveelheid spuitvloeistof per oppervlakte-eenheid) op verschillende hoogtes op $7 \mathrm{~m}$ vanaf het hart van de buitenste bomenrij bij bespuitingen van een kersenperceel met 3 constructies (Open kap, Open kap met suzuki gaas, Dichte kap met suzuki gaas) met een standaard dwarsstroomspuit (Munckhof ECO kap) met ATR lila werveldoppen en met TVI8001 spuitdoppen (90\% driftreducerende dop), lage luchtinstelling en eenzijdig spuiten van de buitenste bomenrij (DRT95).

\begin{tabular}{|c|c|c|c|c|c|c|}
\hline \multirow{2}{*}{$\begin{array}{c}\text { Hoogte } \\
\text { (m) }\end{array}$} & \multicolumn{2}{|c|}{ Open kap } & \multicolumn{2}{|c|}{ Open kap+suzuki gaas } & \multicolumn{2}{|c|}{ Dichte kap+suzuki gaas } \\
\hline & ATR & TVI & ATR & TVI & ATR & TVI \\
\hline 0 & 9,382 & 0,477 & 2,612 & 0,236 & 1,964 & 0,201 \\
\hline 2 & 11,968 & 0,422 & 4,137 & 0,294 & 2,849 & 0,207 \\
\hline 3 & 11,297 & 0,428 & 6,440 & 0,350 & 4,603 & 0,216 \\
\hline 5 & 6,677 & 0,323 & 9,022 & 0,362 & 2,891 & 0,147 \\
\hline 6 & 5,314 & 0,227 & 7,274 & 0,250 & 2,234 & 0,150 \\
\hline 7 & 3,097 & 0,186 & 4,843 & 0,215 & 1,520 & 0,102 \\
\hline 8 & 2,223 & 0,174 & 3,042 & 0,207 & 1,139 & 0,110 \\
\hline
\end{tabular}

Tabel 3.4 Gemiddelde drift naar de lucht (\% van verspoten hoeveelheid spuitvloeistof per oppervlakte-eenheid) op verschillende hoogtes op $7 \mathrm{~m}$ vanaf het hart van de buitenste bomenrij bij bespuitingen van een kersenperceel met 3 constructies (Open kap, Open kap met suzuki gaas, Dichte kap met suzuki gaas) met een standaard dwarsstroomspuit (Munckhof ECO kap) met ATR lila werveldoppen en met TVI8001 spuitdoppen (90\% driftreducerende dop), lage luchtinstelling en eenzijdig spuiten van de buitenste bomenrij (DRT95).

\begin{tabular}{|c|c|c|c|c|c|}
\hline \multirow[b]{2}{*}{ Object } & \multirow[b]{2}{*}{ Techniek } & \multicolumn{4}{|c|}{$\%$ drift op hoogte $(\mathrm{m})$} \\
\hline & & $0-3$ & $3-6$ & $6-10$ & $0-10$ \\
\hline Open kap & ATR & 10,46 a & 8,34 a & 2,63 a & 6,52 a \\
\hline \multirow[t]{2}{*}{ Open kap+suzuki gaas } & ATR & $4,09 \mathrm{~b}$ & $7,93 \mathrm{~b}$ & $3,74 \quad b$ & $4,82 b$ \\
\hline & TVI & $0,28 \mathrm{e}$ & $0,33 \mathrm{~d}$ & $0,19 \mathrm{~d}$ & $0,26 \mathrm{~d}$ \\
\hline Dichte kap+suzuki gaas & TVI & $0,19 \mathrm{f}$ & $0,18 \mathrm{e}$ & $0,13 \mathrm{e}$ & $0,16 \mathrm{e}$ \\
\hline
\end{tabular}

Verschillende letters in een kolom duiden op significante verschillen $(a<0,05)$

In tabel 3.4 is te zien dat over de hele mast $(0-10 \mathrm{~m})$ de bespuiting met ATR Lila spuitdoppen in de open situatie met $6,52 \%$ de hoogste drift geeft. Bespuitingen bij suzuki-fruitvlieggaas geeft een significant lagere drift met 4,82\%. De bespuitingen bij suzuki-fruitvlieggaas gecombineerd met een dichte kap geeft met $2,16 \%$ significant de laagste drift.

Hetzelfde wordt ook gevonden bij de bespuitingen met de TVI8001. De onderlinge verschillen zijn echter niet altijd significant. In figuur 3.2 en 3.3 is te zien dat bij de bespuitingen met ATR lila spuitdoppen bij suzuki-fruitvlieggaas de drift vanaf $4 \mathrm{~m}$ hoogte hoger is dan in de open situatie. Dat is ook te zien in tabel 3.4. Op 6-10 m hoogte is de drift bij de bespuitingen met de ATR lila spuitdop bij suzuki-fruitvlieggaas significant hoger dan in de open situatie. In combinatie met een dichte kap is de drift weer significant lager. Bij de bespuitingen met de TVI8001 is het effect hetzelfde. De onderlinge verschillen zijn echter alleen statistisch significant tussen suzuki-fruitvlieggaas en suzuki-fruitvlieggaas gecombineerd met een dicht regenkap. 


\section{Discussie}

\section{Driftreductie naar de grond}

In tabel 4.1 staan de driftreducties berekend ten opzichte van de referentie situatie (Open kap met ATR Lila spuitdoppen). De driftreductie is uitgerekend voor de volgende zones:

- Voor de bespuiting van de kersen, die geplant zijn op een rijafstand van $4 \mathrm{~m}$, is de standaard teeltvrije zone overeenkomstig de rijafstand minimaal $4 \mathrm{~m}$. Dit houdt in dat de evaluatiezone voor niet-doelwit arthropoden en planten op 3,5-4,5 $\mathrm{m}$ van de laatste bomenrij ligt $(0,50-1,50 \mathrm{~m}$ achter het gaas dat op 3,0 $\mathrm{m}$ van de laatste bomenrij stond).

- Voor de bespuiting van de kersen, die geplant zijn op een rijafstand van $4 \mathrm{~m}$, is de standaard teeltvrije zone overeenkomstig de rijafstand minimaal $4 \mathrm{~m}$. Dit houdt in dat de evaluatiezone voor wateroppervlak op 5,5-6,5 $\mathrm{m}$ van de laatste bomenrij ligt (2,50-3,50 $\mathrm{m}$ achter het gaas dat op 3,0 $\mathrm{m}$ van de laatste bomenrij stond).

- Stroken behorende bij $3 \mathrm{~m}$ teeltvrije zone waarbij de strook 4,5-5,5 m van de laatste bomenrij de standaard evaluatie zone voor DRT-indeling op wateroppervlak is.

- Stroken behorende bij een $4 \frac{1}{2} \mathrm{~m}$ teeltvrije zone.

Tabel 4.1 Gemiddelde driftreductie (\%) ten opzichte van referentie situatie (Open kap, ATR Lila doppen) op verschillende afstanden vanaf het hart van de buitenste bomenrij bij bespuitingen van een kersenperceel met 3 constructies (Open kap, Open kap met suzuki gaas, Dichte kap met suzuki gaas) met een standaard dwarsstroomspuit (Munckhof ECO kap) met ATR lila werveldoppen en met TVI8001 spuitdoppen (90\% driftreducerende dop), lage luchtinstelling en eenzijdig spuiten van de buitenste bomenrij (DRT95).

\begin{tabular}{|c|c|c|c|c|c|c|c|c|}
\hline \multirow{2}{*}{$\begin{array}{l}\text { Afstand tot } \\
\text { buitenste } \\
\text { bomenrij (m) }\end{array}$} & \multicolumn{2}{|c|}{ Open Kap } & \multicolumn{3}{|c|}{ Open kap+suzuki gaas } & \multicolumn{3}{|c|}{ Dichte kap+suzuki gaas } \\
\hline & & & & & TVI open & & & open \\
\hline $31 / 2-41 / 2$ & $\mathrm{a}$ & $\mathrm{c}$ & $b$ & d & & c & $\mathrm{e}$ & \\
\hline $51 / 2-61 / 2$ & $*$ & 93,2 & 52,5 & 96,4 & 47,1 & 91,4 & 99,3 & 90,2 \\
\hline \multirow[t]{2}{*}{$3-7$} & $*$ & 88,4 & 61,9 & 95,6 & 62,3 & 86,2 & 99,3 & 93,9 \\
\hline & a & c & $b$ & $d$ & & c & $\mathrm{e}$ & \\
\hline \multirow[t]{2}{*}{$41 / 2-51 / 2$} & $*$ & 92,1 & 58,9 & 96,3 & 52,9 & 88,6 & 99,3 & 90,5 \\
\hline & $\mathrm{a}$ & c & $\mathrm{b}$ & $d$ & & c & e & \\
\hline $6-7$ & a & c & $\mathrm{b}$ & d & & $\mathrm{c}$ & $\mathrm{e}$ & \\
\hline Gem over alle zones & $*$ & 91,4 & 56,7 & 96,2 & 53,7 & 88,8 & 99,3 & 92,0 \\
\hline Niet getoetst & & & & & & & & \\
\hline
\end{tabular}

Verschillende letters in een rij duiden op significante verschillen $(a<0,05)$

Op de strook 41/2-51/2 m wordt bij bespuitingen met ATR Lila doppen bij gebruik van suzukifruitvlieggaas ten opzichte van de referentie bespuiting (ATR Lila doppen in open situatie) een significante driftreductie gevonden van 58,9\%. Suzuki-fruitvlieggaas gecombineerd met dichte kappen geeft een significante driftreductie van $88,6 \%$. Ten opzichte van de referentiebespuiting geeft de TVI8001 in de open situatie een driftreductie van $92,1 \%$. Bij gebruik van suzuki-fruitvlieggaas en suzuki-fruitvlieggaas gecombineerd met dichte kappen geven de TVI8001 spuitdoppen driftreducties van respectievelijk 96,3\% en 99,3\%. Ten opzichte van de TVI8001 in de open situatie geeft de TVI met suzuki-fruitvlieggaas een driftreductie van 52,9\% en suzuki-fruitvlieggaas gecombineerd met dichte kappen een driftreductie van 90,5\%. De driftreductie door gebruik van suzuki-fruitvlieggaas 
voor beide spuittechnieken is gemiddeld $55,9 \%$ en voor de beide spuittechnieken (standaard $88,6 \%$ en DRT95 90,5\%) in combinatie met suzuki-fruitvlieggaas en dichte regenkappen $89,6 \%$.

De driftreductie bij de bespuitingen met ATR Lila doppen bij gebruik van suzuki-fruitvlieggaas is ten opzichte van de referentiesituatie (ATR Lila, open situatie) gemiddeld $56,7 \%$ over de zones zoals gepresenteerd in tabel 4.1. Bij bespuitingen met de TVI8001 spuitdoppen is de driftreductie door suzuki-fruitvlieggaas gemiddeld over de in tabel 4.1 gepresenteerde zones $96,2 \%$. Ten opzichte van de bespuitingen met TVI8001 spuitdoppen in de open situatie (gemiddeld 91,4\% driftreductie voor de in tabel 4.1 gepresenteerde zones) is dat op basis van de in tabel 3.2 gepresenteerde driftdepositiegetallen een verhoging van de driftreductie van 53,7\% door gebruik van het suzukifruitvlieggaas. De driftreductie bij de bespuitingen met ATR Lila doppen bij gebruik van suzukifruitvlieggaas in combinatie met dichte kappen is ten opzichte van de open situatie gemiddeld over alle in tabel 4.1 gepresenteerde zones $88,8 \%$. Bij de TVI8001 spuitdoppen in combinatie met suzukifruitvlieggaas en dichte kappen is de driftreductie gemiddeld over alle in tabel 4.1 gepresenteerde zones 99,3\%. Ten opzichte van de driftreductie door de TVI8001 in de open situatie is dat, gebaseerd op de driftdepositiegetallen in tabel 3.2, een toename in de driftreductie van $92,0 \%$ door gebruik van de combinatie suzuki-fruitvlieggaas en dichte kappen.

Op de evaluatiestrook voor niet-doelwit planten en arthropoden, in dit geval bij een teeltvrije zone van 4,0 m overeenkomstig de rijafstand van de bomen, op 3,5-4,5 $\mathrm{m}$ van de laatste bomenrij is de driftreductie bij de ATR lila spuitdop en gebruik van suzuki-fruitvlieggaas $66 \%$ en bij gebruik van suzuki-fruitvlieggaas en dichte regenkappen $82,8 \%$. Bij gebruik van de TVI8001 spuitdoppen (DRD90), lage luchtinstelling en eenzijdig spuiten buitenste bomenrij (DRT95) is in de open situatie de driftreductie op de strook 3,5-4,5 m 87,4\%, bij gebruik in combinatie met suzuki-fruitvlieggaas op $3 \mathrm{~m}$ van de laatste bomenrij $95,1 \%$ en bij de combinatie met suzuki-fruitvlieggaas en dichte regenkap $99,3 \%$.

De driftreductie van de $95 \%$ driftreducerende techniek combinatie (90\% driftreducerende spuitdop, lage luchtinstelling en eenzijdig spuiten buitenste bomenrij) geeft in deze driftmetingen op 4,5-5,5 m van de laatste bomenrij een iets lagere driftreductie van 92,1\%. Dit wijkt af van eerdere meetresultaten op basis waarvan de techniek combinatie ingedeeld is in de DRT95 driftreductieklasse (Wenneker et al., 2004, 2005). Oorzaak hiervan kan liggen in:

- de (weers)omstandigheden waaronder deze driftmetingen uitgevoerd zijn;

- een kersenboomgaard die afwijkt van een appelboomgaard waar doorgaans de driftmetingen in uitgevoerd werden door een hogere boomkroon (3,3 $\mathrm{m}$ tov 2,75 m);

- andere bladdichtheid, boom- en snoeivorm van de kersenbomen t.o.v. de appelbomen;

- bredere rijafstand van de bomenrijen (4,0 m tov 3,0 m);

- een andere standaard spuit (Munckhof dwarsstroom met ECO kap tov DWK kap) maar met dezelfde ventilator en luchtopbrengst maar anders verdeeld (minder dwars en meer omhoog gericht);

- andere 90\% driftreducerende spuitdoppen (Albuz TVI8001 bij 9 bar t.o.v. Lechler ID9001 bij 5 bar).

Gezien alle verschillen in uitvoeringsomstandigheden zit de gemeten driftreductie van de DRT95 wel in de verwachte orde van grootte; ruim boven de 90\% driftreductie. Zande et al. (2019) geeft aan dat voor een serie van 120 driftmetingen (1990-2011) met de referentie boomgaardspuit in de volblad situatie van appelboomgaarden (temperatuur $13-23^{\circ} \mathrm{C}$, windsnelheid 2,5-3,9 m/s) de driftdepositie op $5 \mathrm{~m}$ afstand van de laatste bomenrij tussen de $5,4 \%$ en $21 \%$ zit (resp. 10 - en 90 -percentiel waarden) bij een gemiddelde driftdepositie van $11,7 \%$ (mediaan 11\%). Deze spreiding in driftdepositie voor de standaard techniek geeft aan dat de gevonden afwijking van de driftreductie in deze metingen voor de DRT95 binnen de spreiding ligt die men op grond van Zande et al. (2019) kan verwachten voor zowel de standaard techniek als de driftreducerende techniek. 


\section{Driftreductie naar de lucht}

Bij de drift naar de lucht op $7 \mathrm{~m}$ afstand van de laatste bomenrij wordt gemiddeld over de hele mast (0-10 m) bij bespuitingen met ATR Lila doppen bij gebruik van suzuki-fruitvlieggaas ten opzichte van de referentie bespuiting (ATR Lila doppen in open situatie) een significante driftreductie gevonden van $26,0 \%$. Suzuki-fruitvlieggaas gecombineerd met dichte kappen geeft een significante driftreductie van $66,8 \%$. Ten opzichte van de referentiebespuiting geeft de TVI8001 in de open situatie een driftreductie van $95,5 \%$. Bij gebruik van suzuki-fruitvlieggaas en suzuki-fruitvlieggaas gecombineerd met dichte kappen geven de TVI8001 spuitdoppen driftreducties van respectievelijk 96,1\% en 97,6\%.

Tabel 4.2 Gemiddelde driftreductie (\%) ten opzichte van referentie situatie (Open kap, ATR Lila doppen) op verschillende hoogtes op $7 \mathrm{~m}$ afstand vanaf het hart van de buitenste bomenrij bij bespuitingen van een kersenperceel met 3 constructies (Open kap, Open kap met suzuki gaas, Dichte kap met suzuki gaas) met een standaard dwarsstroomspuit (Munckhof ECO kap) met ATR lila werveldoppen en met TVI8001 spuitdoppen (90\% driftreducerende dop), lage luchtinstelling en eenzijdig spuiten van de buitenste bomenrij (DRT95).

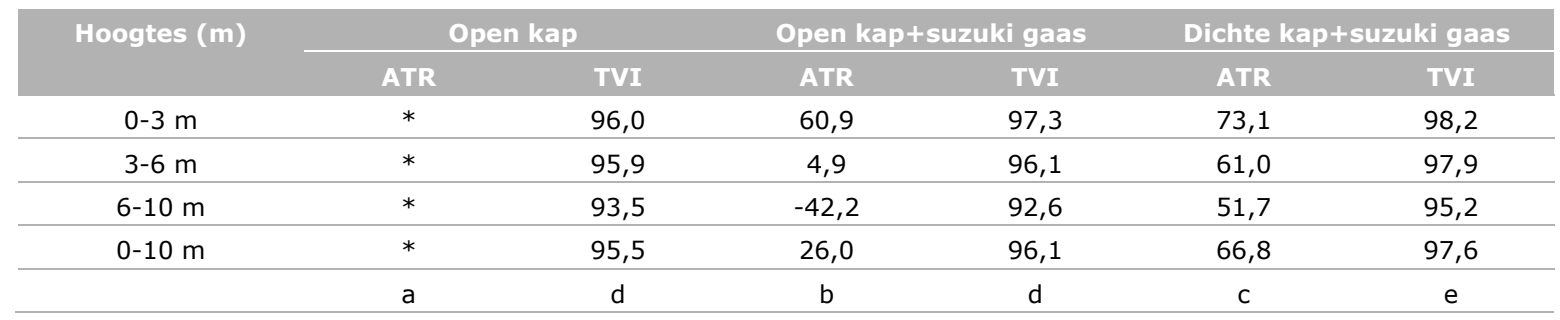

Verschillende letters in een rij duiden op significante verschillen $(a<0,05)$

De lage driftreductie naar de lucht voor de combinatie ATR lila dop en suzuki-fruitvlieggaas wordt vooral veroorzaakt door een toename van de drift (42\%) op 6-10 m hoogte. Achter het gaas op 0-3 m hoogte is de driftreductie hierbij namelijk $61 \%$.

\section{Aantal herhalingen}

In totaal werden 8 herhalingen gemeten. Bij één bespuiting met de ATR Lila dop bij de open kappen (\#1) en één bespuiting van de ATR Lila doppen in combinatie met dichte kap+suzuki-fruitvlieggaas (\#1) week de gemiddelde windhoek te veel af van haaks op de bomenrij. Deze metingen zijn niet verwerkt in de gepresenteerde resultaten. Bij deze twee combinaties zijn de drift resultaten gebaseerd op 7 herhalingen, bij de overige combinaties op 8 herhalingen. Bij alle 8 herhalingen is de driftdepositie van de referentie bespuiting (ATR Lila dop en open kap) op de strook 4,5-5,5 $\mathrm{m}$ van de laatste bomenrij $11,162 \%$ waar die bij de 7 herhalingen $11,620 \%$ is. De driftdepositie wordt bij een nauwere windhoek dus iets hoger. Dit heeft effect op de berekening van de driftreductie die ten opzichte van deze waarde uitgerekend wordt. De driftreductie voor de volledige 8 herhalingen (inclusief de te grote windhoek voor de standaard) is in tabel 4.3 weergegeven voor de water (4,5-5,5 m) en de niet-doelwit planten/arthropoden (3,5-4,5 m) evaluatie zones. Voor de bespuiting met de ATR Lila doppen in combinatie met dichte kap+suzuki-fruitvlieggaas geldt hetzelfde; de driftdepositie op de strook 4,5-5,5 m neemt van $1.250 \%$ naar $1.319 \%$ toe. Hierdoor verandert de berekende driftreductie voor deze combinatie van $88,8 \%$ naar $88,6 \%$. 
Tabel 4.3 Gemiddelde driftreductie (\%) ten opzichte van referentie situatie (Open kap, ATR Lila doppen) bij alle gemeten herhalingen $(n=8)$ op twee verschillende afstanden vanaf het hart van de buitenste bomenrij bij bespuitingen van een kersenperceel met 3 constructies (Open kap, Open kap met suzuki gaas, Dichte kap met suzuki gaas) met een standaard dwarsstroomspuit (Munckhof ECO kap) met ATR lila werveldoppen en met TVI8001 spuitdoppen (90\% driftreducerende dop), lage luchtinstelling en eenzijdig spuiten van de buitenste bomenrij (DRT95).

\begin{tabular}{ccccccc} 
Afstand tot buitenste & \multicolumn{2}{c}{ Open kap } & \multicolumn{2}{c}{ Open kap+suzuki gaas } & Dichte kap+suzuki gaas \\
\cline { 2 - 7 } bomenrij $(\mathrm{m})$ & ATR & TVI & ATR & TVI & ATR \\
\hline $31 / 2-41 / 2$ & $*$ & 87,2 & 65,4 & 95,0 & 82,8 \\
\hline $41 / 2-51 / 2$ & $*$ & 91,8 & 57,2 & 96,1 & 88,6 & 99,2 \\
\hline
\end{tabular}

Uit de vergelijking van de driftreductie voor de 8 gemeten herhalingen (inclusief te grote afwijking van de windhoek; tabel 4.3) en de driftreductie bij weglaten van de metingen bij te grote windhoek bij de standaard bespuiting (ATR lila dop en open kap) en van de combinatie ATR lila dop en dichte kap + suzuki-fruitvlieggaas (tabel 4.1) blijkt dat er slechts kleine verschillen zijn. Door het niet meenemen van de herhalingen met een te grote windhoek in de presentatie van de berekende driftreductie blijft deze gelijk (TVI en dichte kap+suzuki-fruitvlieggaas) of wordt deze iets hoger $(0,1 \%-0,3 \%$ ). Bij de ATR en open kap en suzuki-fruitvlieggaas is de toename in de driftreductie het hoogst namelijk $0,6 \%$ op de zone $3,5-4,5 \mathrm{~m}$ en $1,7 \%$ op de zone $4,5-5,5 \mathrm{~m}$.

Het weglaten van de bespuitingen met een hoge windhoek leidt dus in dit geval tot een hogere driftdepositie voor de standaard bespuiting (ATR lila + open kap) en daardoor iets hogere driftreductie getallen op de verschillende evaluatiestroken. De indeling in de verschillende driftreductieklassen van de verschillende combinaties is hierdoor niet veranderd. 


\section{$5 \quad$ Conclusies}

Bij driftmetingen, met een vergelijkbare spuit als de referentiespuit aangepast aan de teelt waarin de metingen gedaan zijn (aangepaste luchtkast), werd tijdens bespuitingen van een kersenboomgaard in het volblad stadium (BBCH 90/92) met ATR lila spuitdoppen en het plaatsen van suzuki-fruitvlieggaas in vergelijking met de referentiebespuiting bij een $3 \mathrm{~m}$ teeltvrije zone op de strook $41 \frac{1}{2}-51 \frac{1}{2} \mathrm{~m}$ vanaf de buitenste bomenrij een driftreductie gevonden van 58,9\%. Door het plaatsen van suzuki-fruitvlieggaas in combinatie met dichte regenkappen werd een driftreductie gevonden van $88,6 \%$.

Bij driftmetingen met 90\% driftreducerende TVI8001 spuitdoppen ( 9 bar), lage luchtinstelling en eenzijdig spuiten van de buitenste bomenrij (DRT95) werd in de open situatie een driftreductie gevonden van $92,1 \%$. Door het plaatsen van suzuki-fruitvlieggaas werd met deze techniek een driftreductie gevonden van $96,3 \%$. Door het plaatsen van suzuki-fruitvlieggaas en dichte regenkappen werd met deze techniek een driftreductie gevonden van 99,3\%.

Bij bespuitingen met TVI 8001 spuitdoppen (DRT95) en suzuki-fruitvlieggaas is de driftreductie op de zone $4 \frac{1}{2}-51 \frac{1}{2} \mathrm{~m}$ vanaf de buitenste bomenrij ten opzichte van de open situatie $52,9 \%$ hoger dan de driftreductie van de DRT95 techniek op zich. Hierdoor kan gesteld worden dat alle technieken gecombineerd met suzuki-fruitvlieggaas (standaard 58,9\%, DRT95 52,9\%) gemiddeld een 55,9\% hogere driftreductie geven door toepassing van het suzuki-fruitvlieggaas en daardoor één DRT-klasse hoger vallen dan de driftreducerende techniek zelf.

Door het plaatsen van suzuki-fruitvlieggaas en regenkappen is de driftreductie op de zone $41 / 2-51 \frac{1}{2} \mathrm{~m}$ vanaf de buitenste bomenrij bij de bespuitingen met TVI 8001 spuitdoppen (DRT95) de bijdrage door suzuki-fruitvlieggaas en regenkappen op de driftreductie gemiddeld 90,5\% hoger dan de driftreductie van deze techniek in de open situatie.

Gemiddeld voor de beide gemeten toedieningstechnieken is de hogere driftreductie (standaard $88,6 \%$, DRT95 90,5\%) door toepassing van suzuki-fruitvlieggaas en regenkappen 89,6\%. Hierdoor kan gesteld worden dat alle technieken gecombineerd met suzuki-fruitvlieggaas en regenkappen zeker twee DRT-klassen (standaard) en drie driftreductieklassen hoger vallen dan de driftreducerende techniek (DRT95) zelf.

Door het plaatsen van suzuki-fruitvlieggaas wordt de drift naar de lucht zowel bij de ATR Lila spuitdoppen als bij de bespuitingen met de TVI8001 doppen (DRT95) de drift boven (6-10 m) in de mast hoger in vergelijking met de standaard bespuiting. Dit effect wordt weer minder als suzukifruitvlieggaas wordt gecombineerd met dichte regenkappen. Gemiddeld over 0-10 m hoogte was op $7 \mathrm{~m}$ afstand van de laatste bomenrij de driftreductie naar de lucht bij bespuiting met de ATR lila spuitdoppen door het plaatsen van suzuki-fruitvlieggaas $26,0 \%$ ten opzichte van de open situatie en door het plaatsen van suzuki-fruitvlieggaas en dichte regenkap 66,8\%. Bij bespuiting met de TVI8001 spuitdop (DRD90), lage luchtinstelling en eenzijdig spuiten van de buitenste bomenrij (DRT95) was de driftreductie naar de lucht (0-10 $\mathrm{m}$ hoog) in de open situatie 95,5\%, door het plaatsen van suzukifruitvlieggaas $96,1 \%$ en door plaatsing van suzuki-fruitvlieggaas en dichte regenkap $97,6 \%$. 


\section{Literatuur}

Ctgb, 2018. Evaluation Manual for the Authorisation of Plant protection products and Biocides according to Regulation (EC) No 1107/2009 NL part Plant protection products. Chapter 6 Fate and behaviour in the environment: behaviour in surface water and sediment version 2.2; January 2018. http://www.ctgb.nl/

EZ, 2013. Gezonde Groei, Duurzame Oogst. Tweede nota duurzame gewasbescherming, periode 2013 tot 2023. Ministerie van Economische Zaken, Den Haag. 2013. 46p.

Gezondheidsraad, 2014. Gewasbescherming en omwonenden. Gezondheidsraad, publicatienr. 2014/02, Den Haag. 2014. 194p.

Huijsmans, J.F.M., H.A.J. Porskamp \& J.C. van de Zande, 1997. Drift(beperking) bij de toediening van gewasbeschermingsmiddelen. Evaluatie van de drift van spuitvloeistof bij bespuitingen in de fruitteelt, de volveldsteelten en de boomteelt (stand van zaken december 1996). IMAG-DLO Rapport 97-04, IMAG, Wageningen, 38 pp.

I\&W, 2017. Regeling van de Staatssecretaris van Infrastructuur en Waterstaat, van 10 november 2017, nr. IENM/BSK-2017/254105, tot wijziging van de Activiteitenregeling in verband met de vermindering van emissies van gewasbeschermingsmiddelen in de glastuinbouw en open teelten. Staatscourant $2017 \mathrm{Nr} .60506$

ISO 22866, 2005. Equipment for crop protection - Methods for the field measurement of spray drift. International Standardisation Organisation, Geneva. 2005.

ISO 22369, 2006. Crop protection equipment - Drift classification of spraying equipment. Part 1. Classes. International Organization for Standardization, Geneva.

Michielsen, J.M.G.P., Wenneker, M., Zande, JC van de \& Heijne, B., 2007. Contribution of individual row sprayings to airborne drift spraying an apple orchard. In: E. Gil, F. Solanelles, S. Planas, J.R. Rossell \& L. Val (eds). 8th Workshop on Spray Apllication Techniques in Fruit Growing June 2005 Barcelona, Book of Abstracts, Universitat Politècnica de Catalunya, Generalitat de Catalunya, Universitat de Lleida, Barcelona, 2007. p.37-46

TCT, 2017a. Beoordelingssystematiek emissiereducerende maatregelen open teelt. versie 15 december 2017. [https://www.helpdeskwater.nl/onderwerpen/emissiebeheer/agrarisch/openteelt/driftreducerende/]

TCT, 2017b. Meetprotocol vaststellen driftreductie spuittechnieken [versie 1 juli 2017].

[https://www.helpdeskwater.nl/onderwerpen/emissiebeheer/agrarisch/openteelt/driftreducerende/]

TCT, 2019. Lijst met indeling van spuittechnieken in Driftreducerende Techniek-klassen (DRT-klassen) (DRT-lijst). [https://www.helpdeskwater.nl/onderwerpen/emissiebeheer/agrarisch/openteelt/driftreducerende/]

TCT, 2020. Lijst met indeling van spuitdoppen in Driftreducerende Dop-klassen (DRD-klassen) (DRDlijst). [https://www.helpdeskwater.nl/onderwerpen/emissiebeheer/agrarisch/openteelt/driftreducerende/]

VSN International, 2019. Genstat for Windows 20th Edition. VSN International, Hemel Hempstead, UK.

VW, VROM, LNV, 2007. Wijziging van het Lozingenbesluit open teelt en veehouderij en enige andere besluiten (actualisering lozingenvoorschriften). Staatsblad 2007 143, 35p.

Wenneker, M., B. Heijne \& J.C. van de Zande, 2004. Invloed venturi-spleetdoppen en luchtondersteuning op emissies bij bespuitingen in de fruitteelt. Praktijkonderzoek Plant \& Omgeving, sector Fruit, PPO-fruit Rapport 2004-03, Randwijk, 2004.

Wenneker, M., B. Heijne \& J.C. van de Zande, 2005. Effect of air induction nozzle (coarse droplet), air assistance and one-sided spraying of the outer tree row on spray drift in orchard spraying. Annual Review of Agricultural Engineering, Vol. 4 (1): 116 - 128.

Zande, J.C. van de, M.C. Butler Ellis, M. Wenneker, P.J. Walklate \& M. Kennedy, 2014. Spray drift and bystander risk from fruit crop spraying. International Advances in Pesticide Application, Aspects of Applied Biology 122, 2014. p. 177-186.

Zande, J.C. van de, H.J. Holterman, J.F.M. Huijsmans \& M. Wenneker, 2019. Spray drift for the assessment of exposure of aquatic organisms to plant protection products in the Netherlands. Part 2: Sideways and upward sprayed fruit and tree crops. Wageningen UR, WPR Report 564, Wageningen. 2019. 86p. 


\section{Bijlage 1 Script statistische analyse}

IRREML

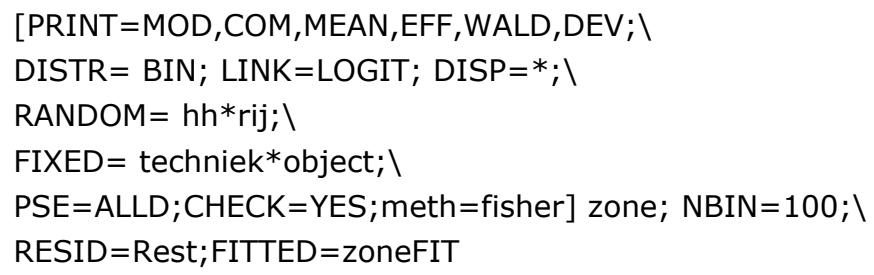

Bij FIXED:

- techniek = spuittechniek

- object= (open situatie, suzuki-gaas en suzuki-gaas in combinatie met dichte kappen 


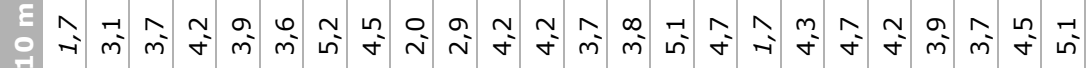

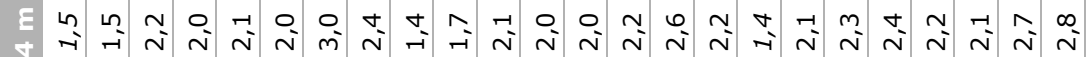

E

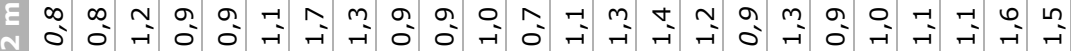

$\frac{1}{\sigma}$
$\frac{1}{1}$
$\frac{1}{ \pm}$
$\frac{1}{ \pm}$
$\frac{1}{0}$

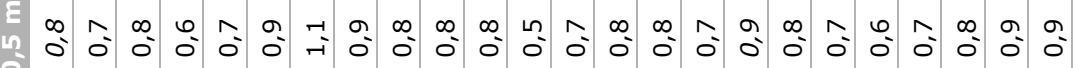

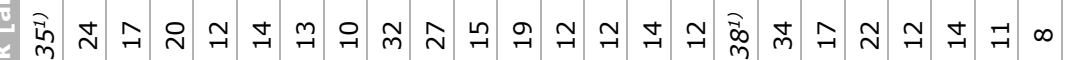

U

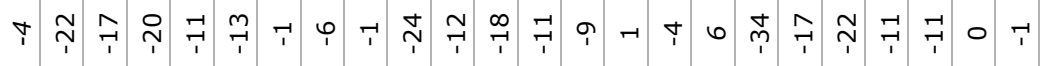

$\frac{\text { U }}{0}$

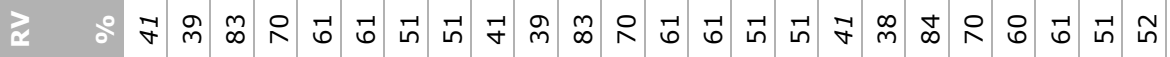

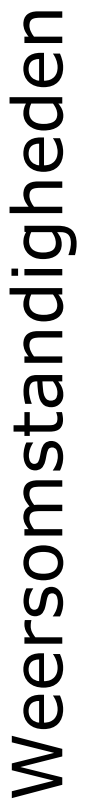

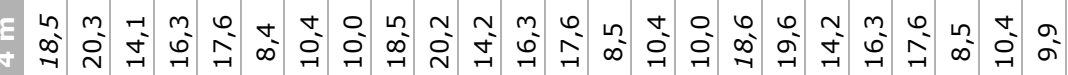

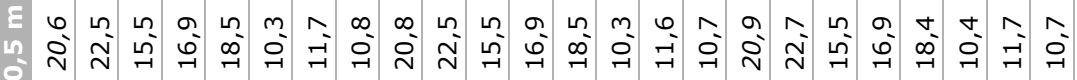

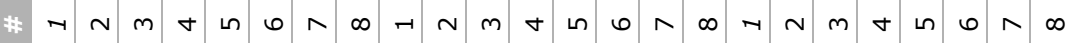

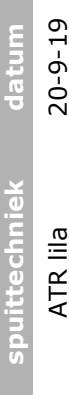

$\vec{O}$
$\stackrel{1}{1}$
$\vec{m}$

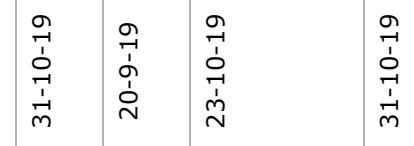

N

(1)

O)

$\frac{\pi}{10}$

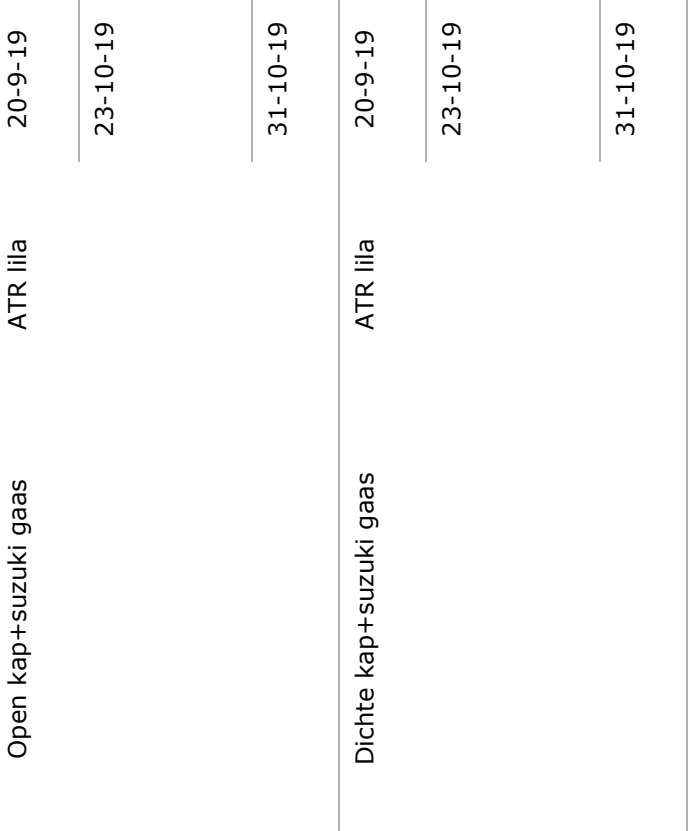

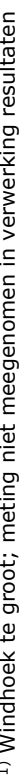




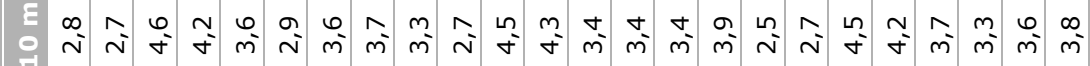

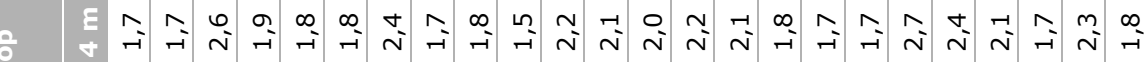

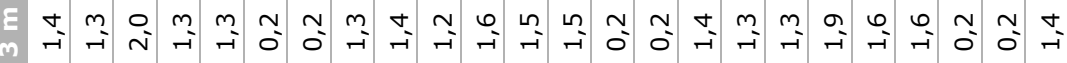

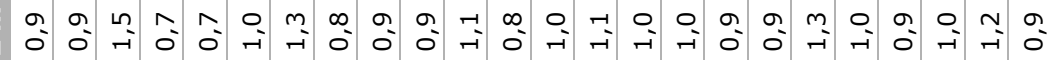

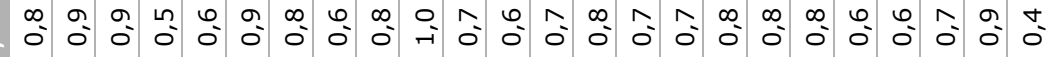

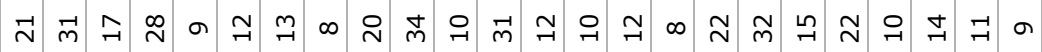

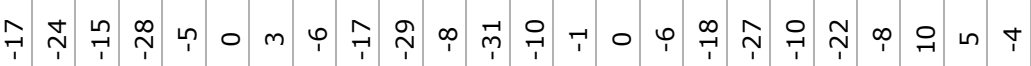

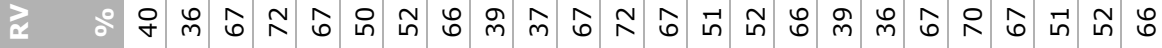

$\div$

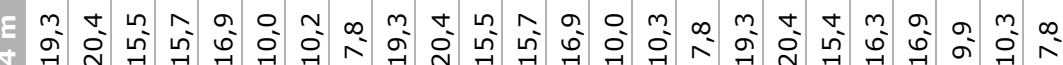

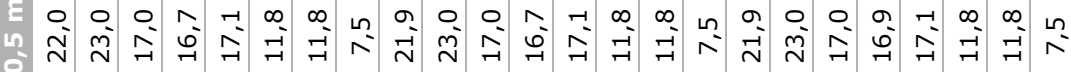

\#H

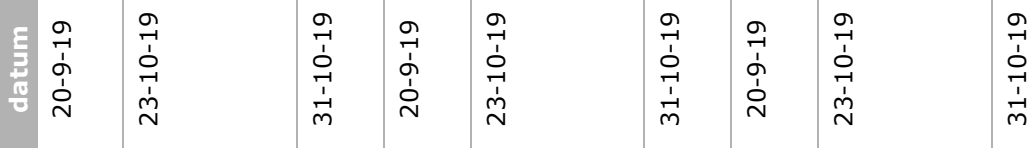

$\frac{2}{2}$

$\stackrel{5}{F}$

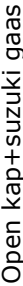

0
0
0
0
0
0
0
0
0
4
0
0
0
0
0
0
0
0 


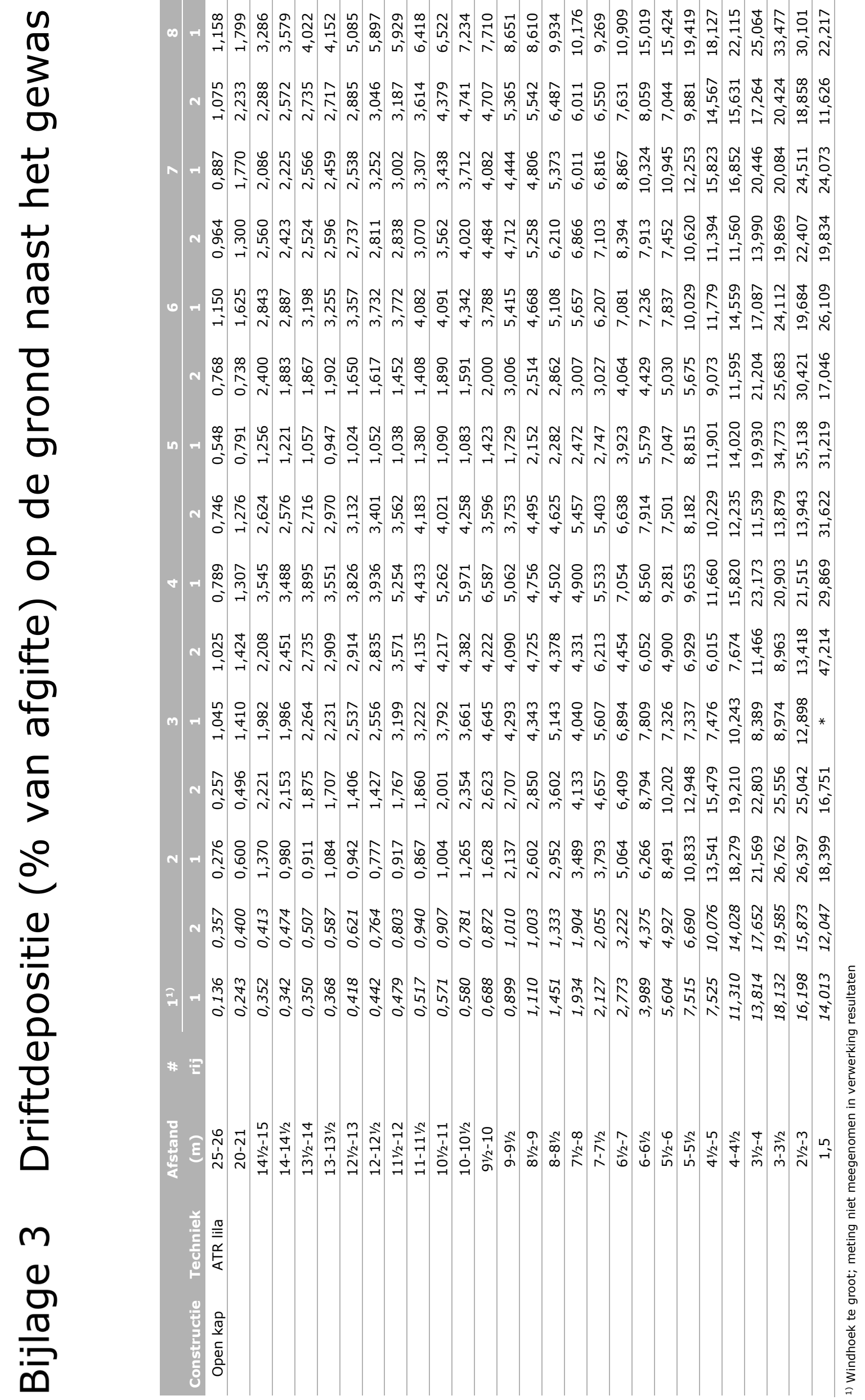




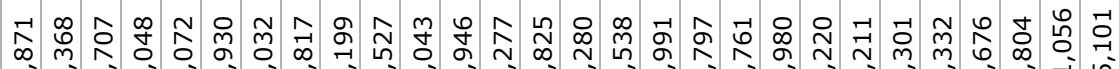
-i N

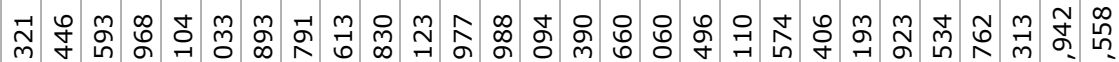
Niver

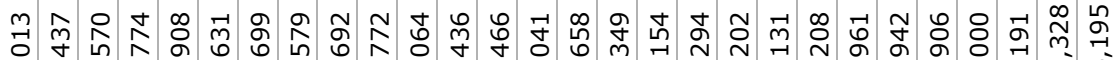

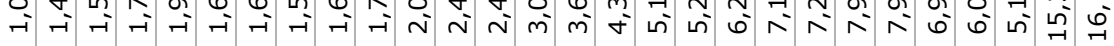

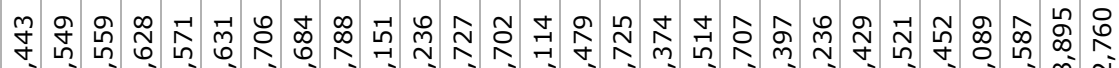

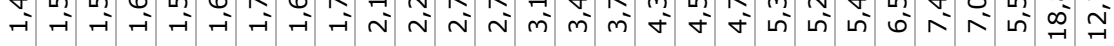
足

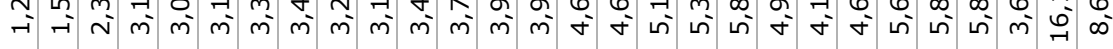

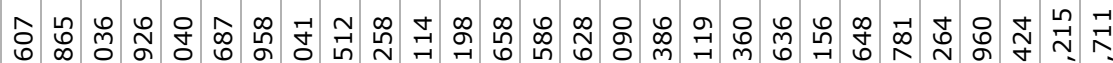

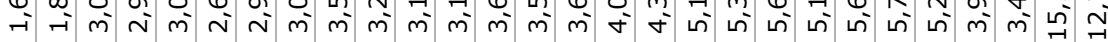

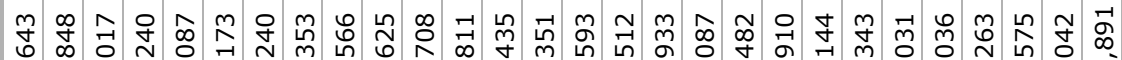

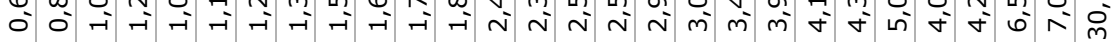

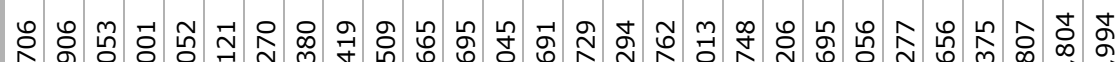

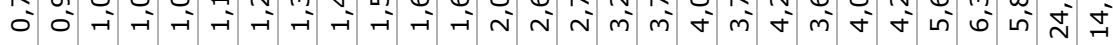

v o.

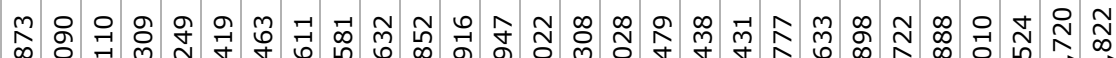

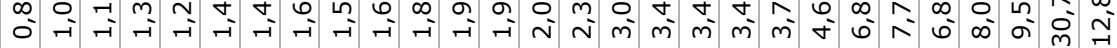

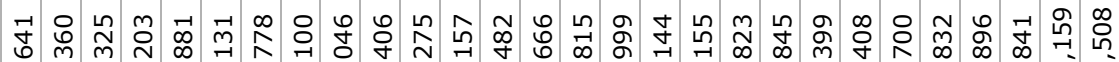
O-

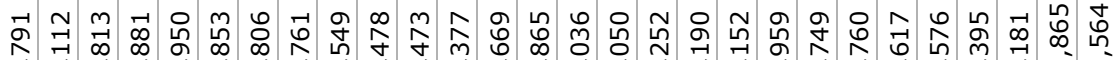

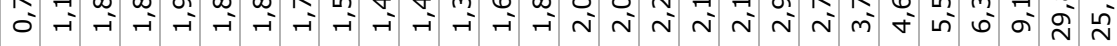

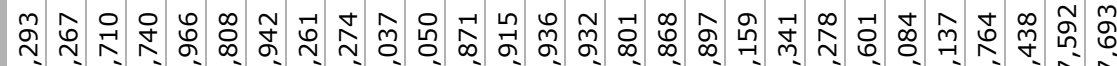

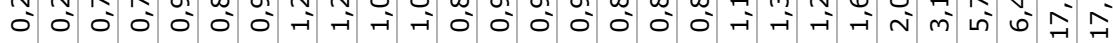

串

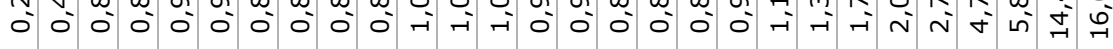

N \begin{tabular}{l}
$g$ \\
\hline
\end{tabular}

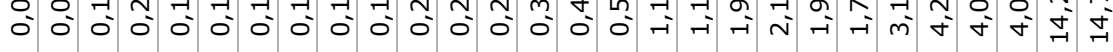

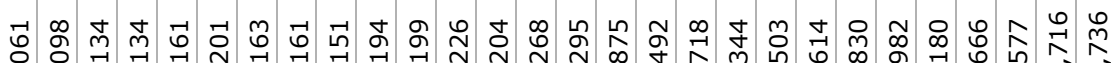

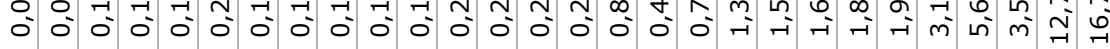

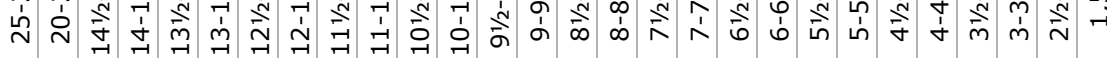

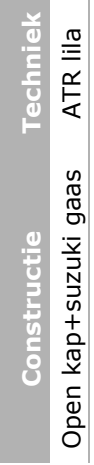




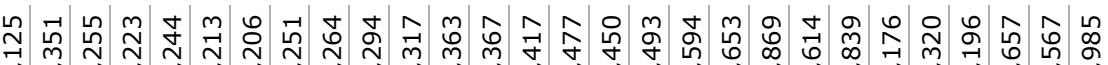

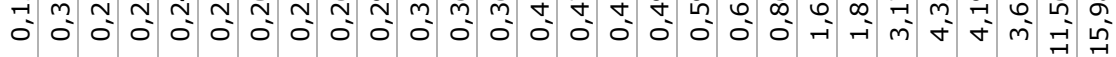

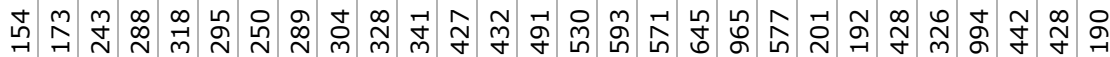

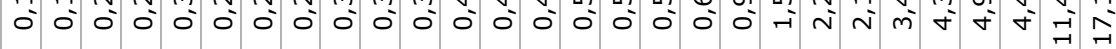

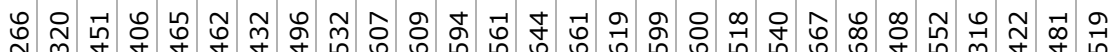
ól 0 o

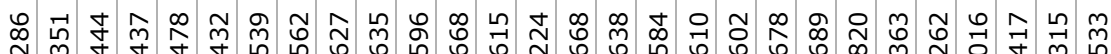
o

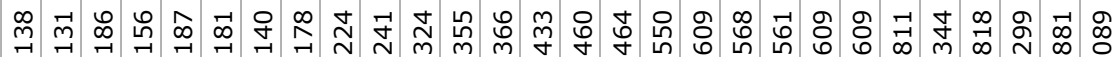
o

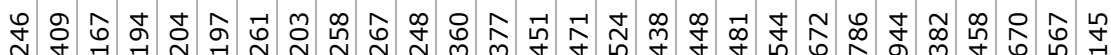

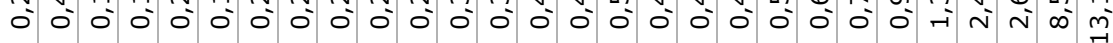

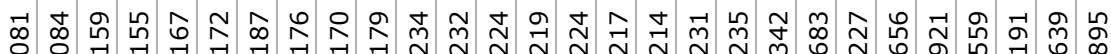
o 0 0. ด̊

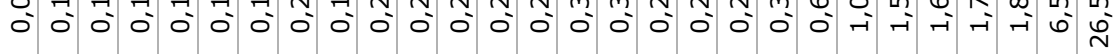

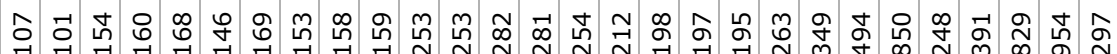

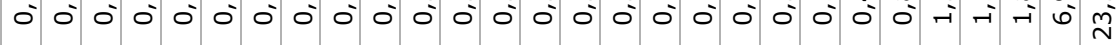
m

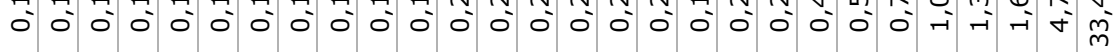

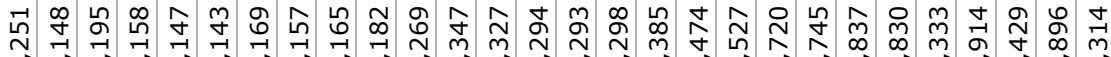
o 0 o

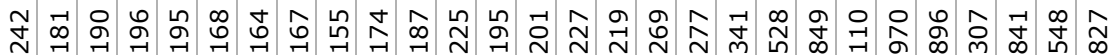

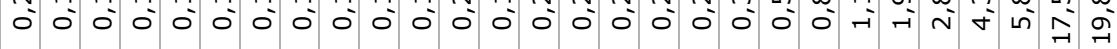

₹ $\begin{aligned} & t \\ & 0\end{aligned}$

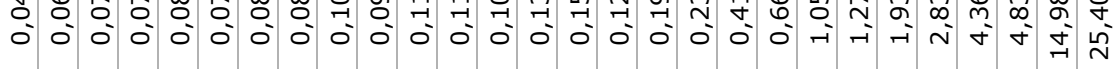

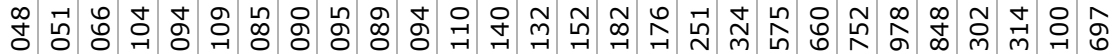

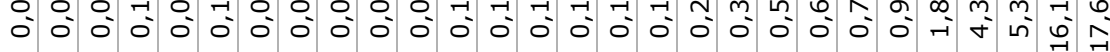

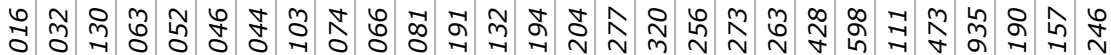

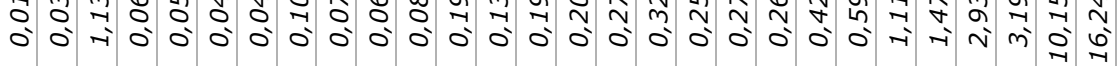

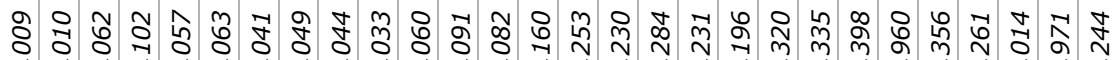

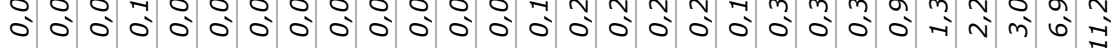

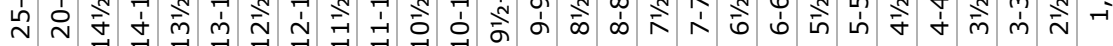




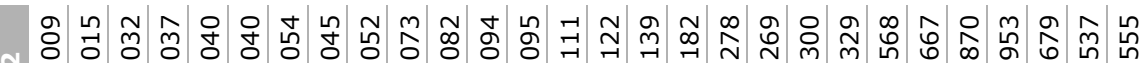

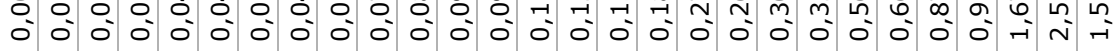

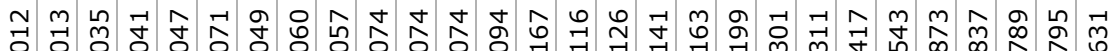

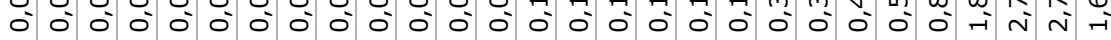

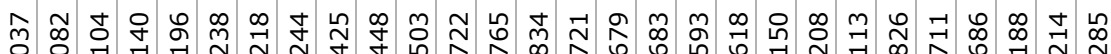

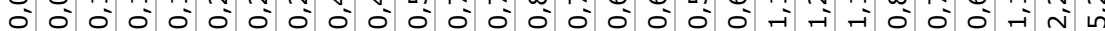

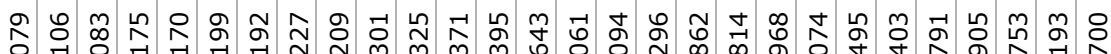

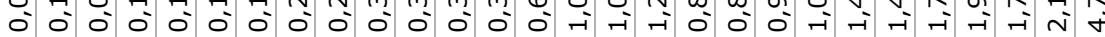

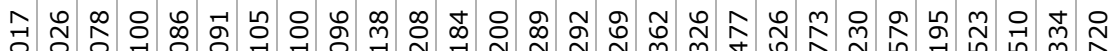

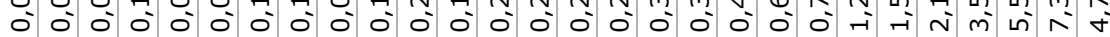

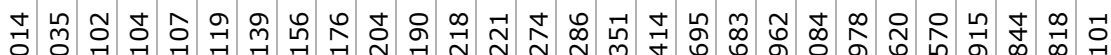

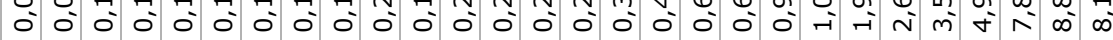

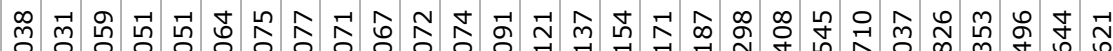

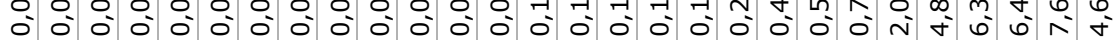

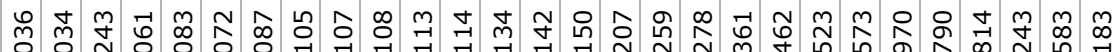

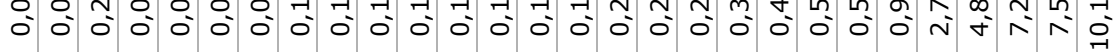

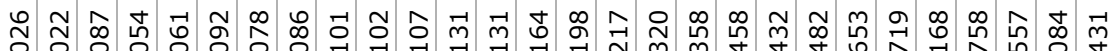

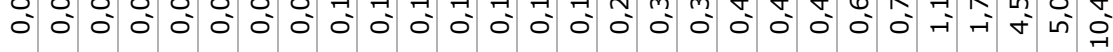

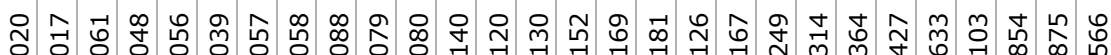

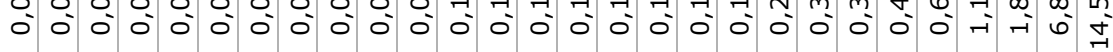

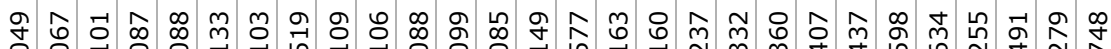

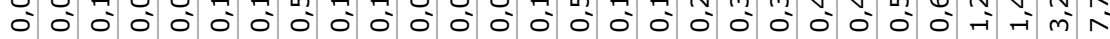

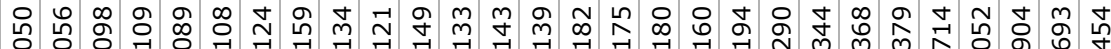

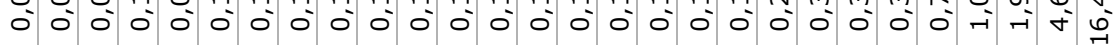

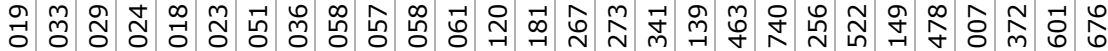

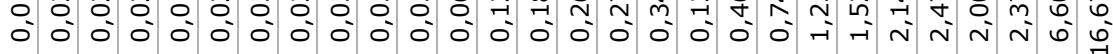

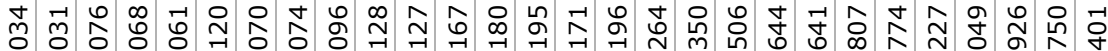

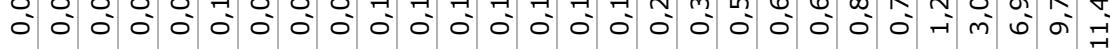

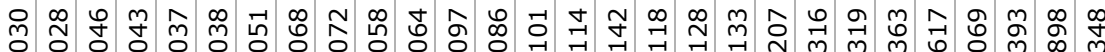

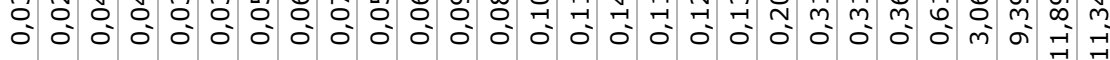

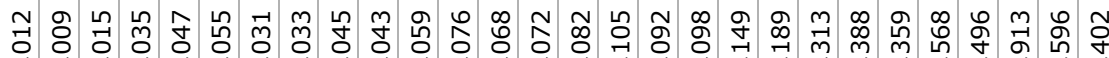

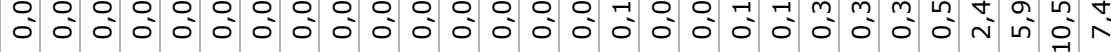

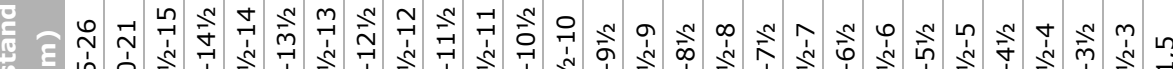
岗 


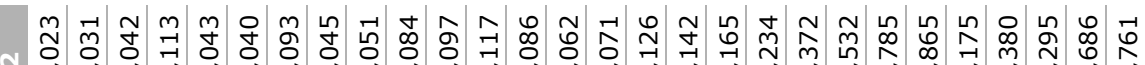

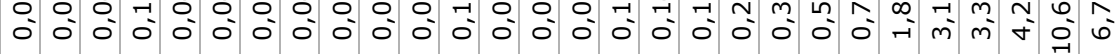

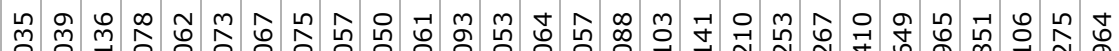

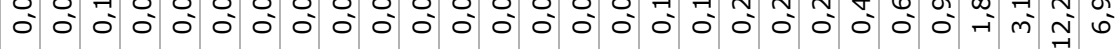

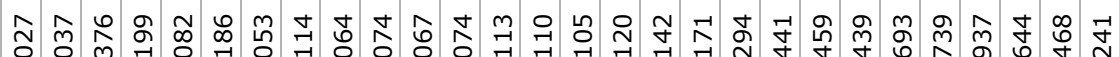

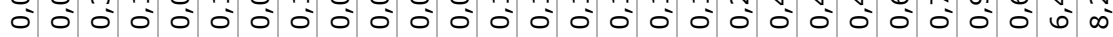

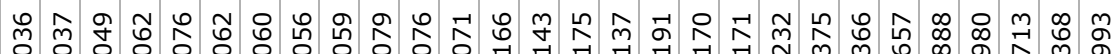

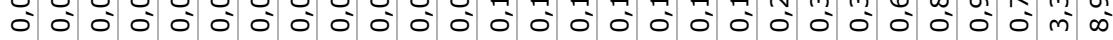

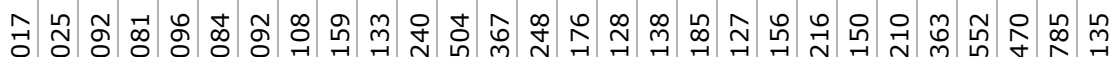

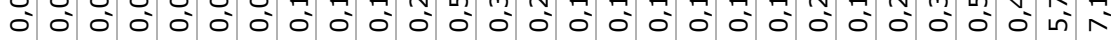

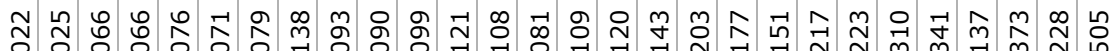

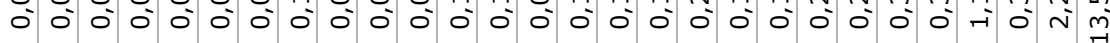
承 స̃丶

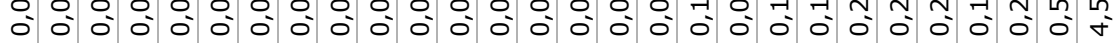

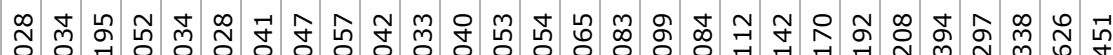

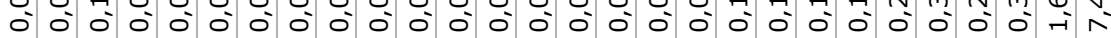

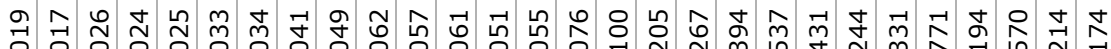

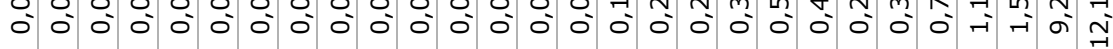

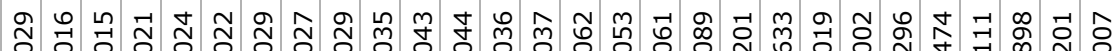

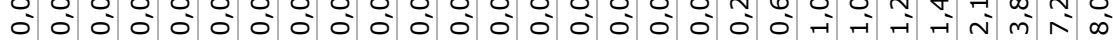

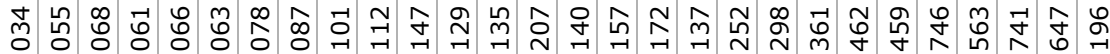

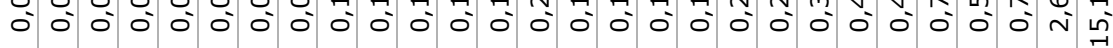

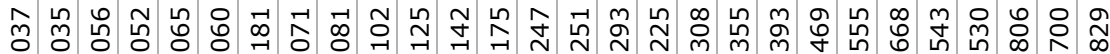

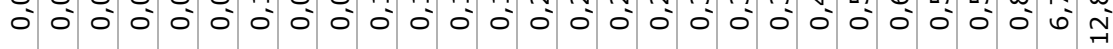

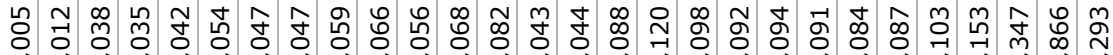
ó

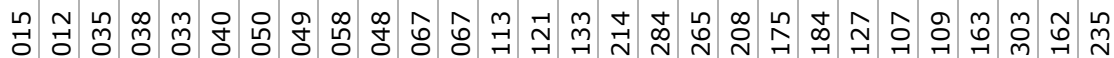

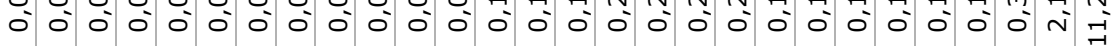

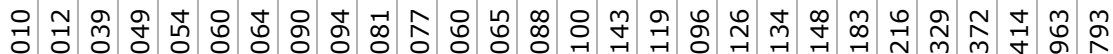

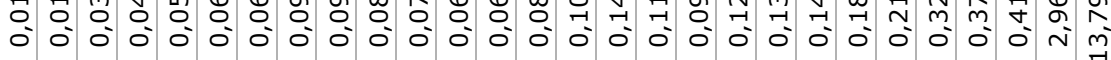

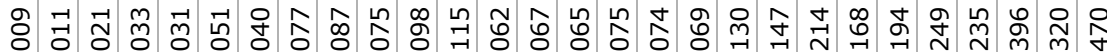

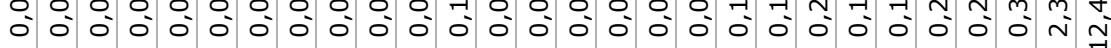

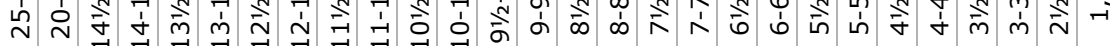




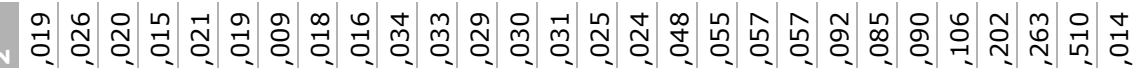

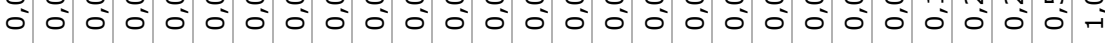

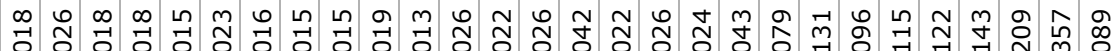

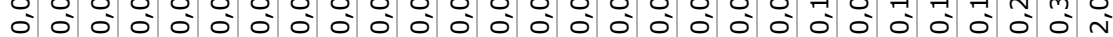
Fี 공 공

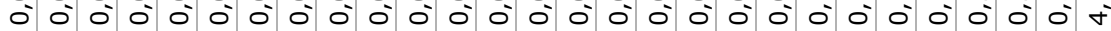

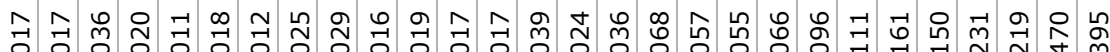
ó

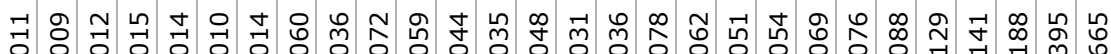

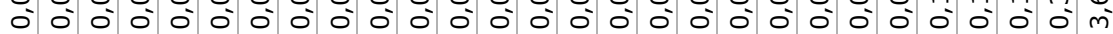

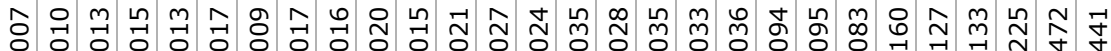

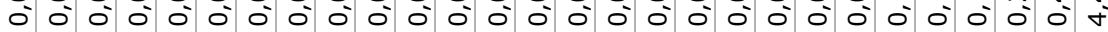

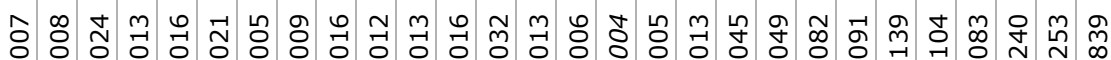

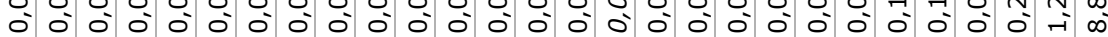

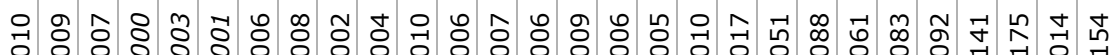

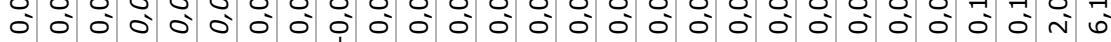

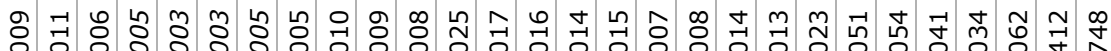

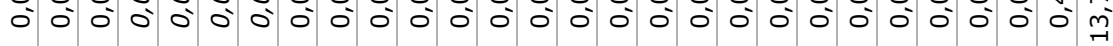

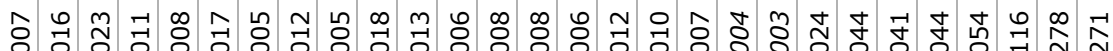
o

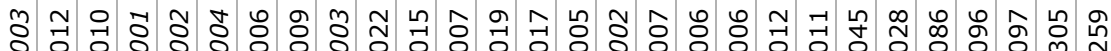
o.

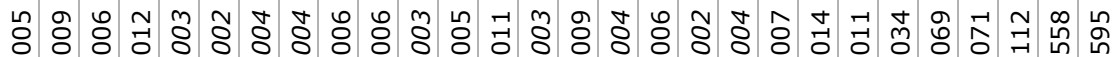

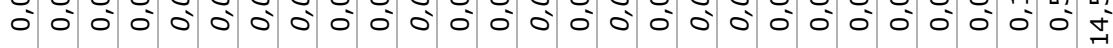

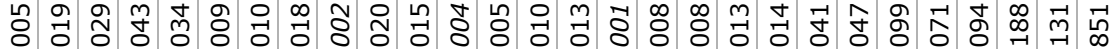

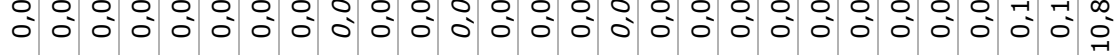

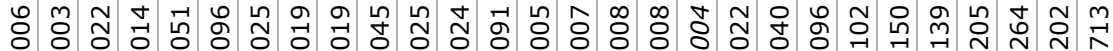

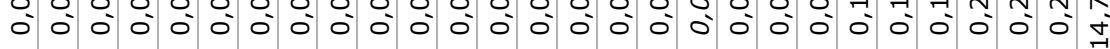

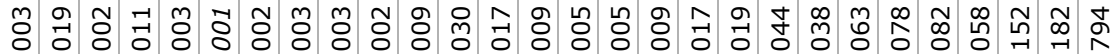

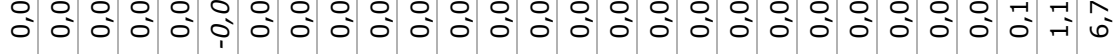

号

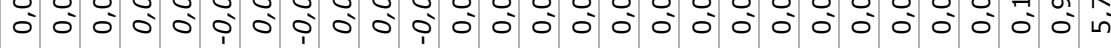

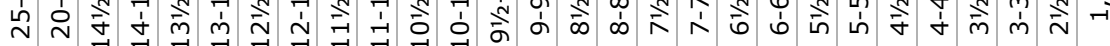




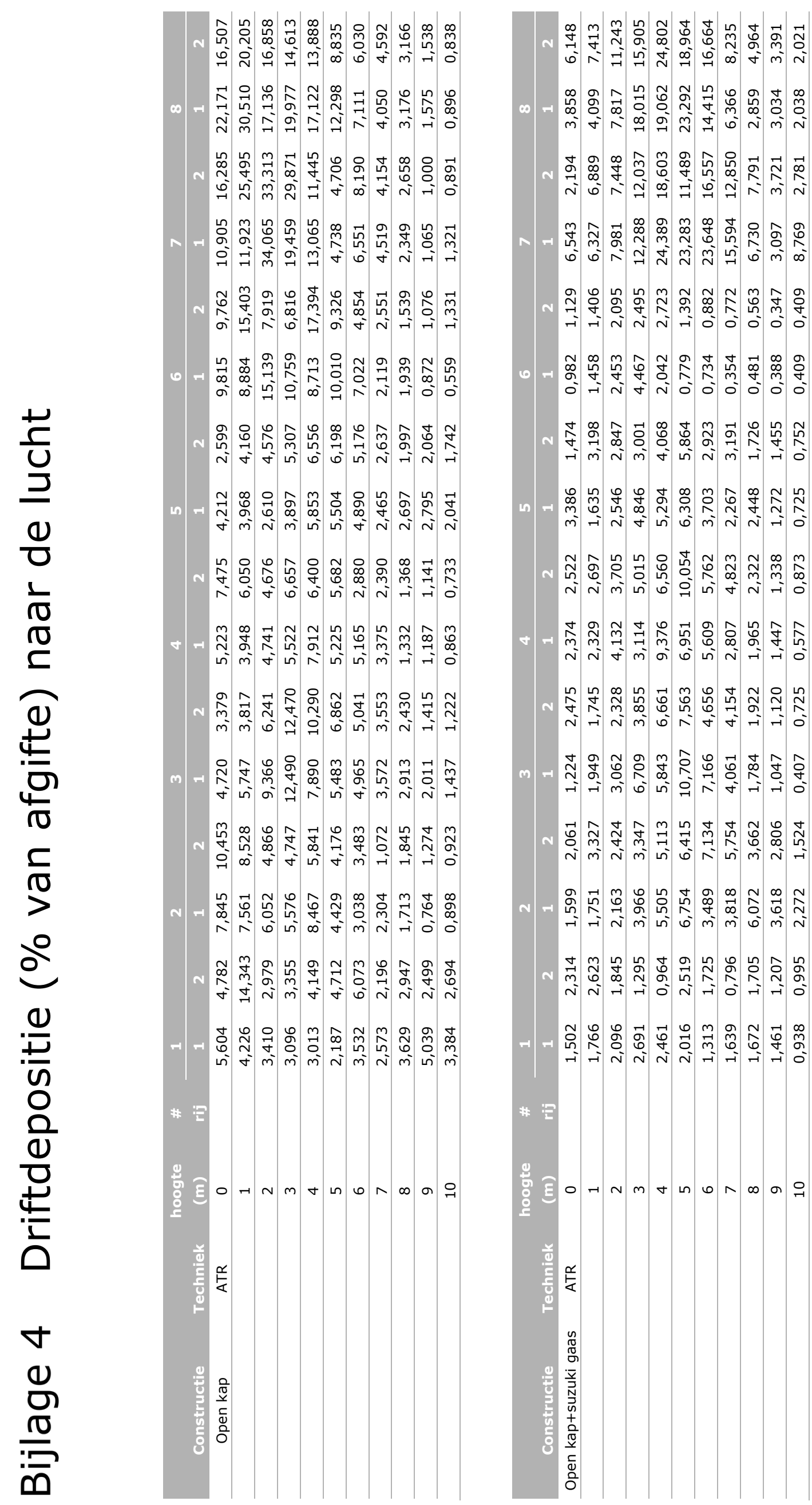




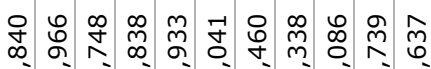
it

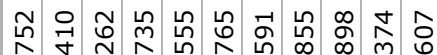

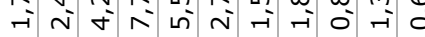

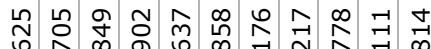

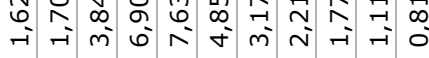
นก ᄂ -

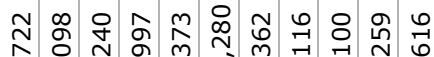
స.

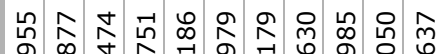

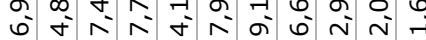

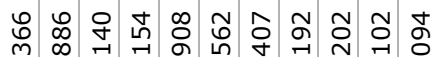
o.

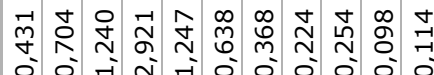

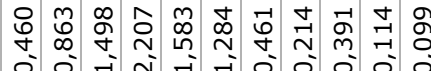
- 0000

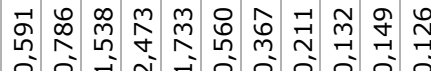
亲 N

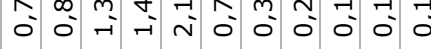

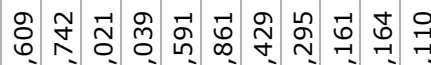
o. 0 o

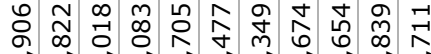

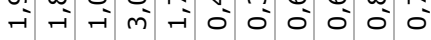

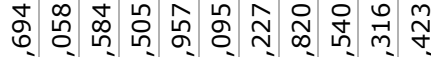

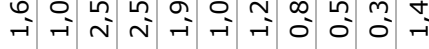

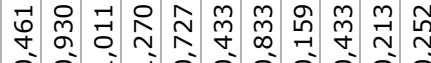

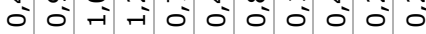

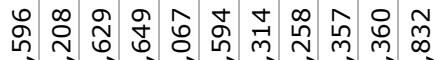
o H

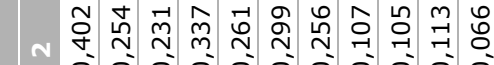
o. 00

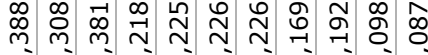

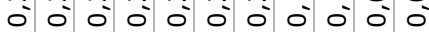

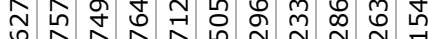

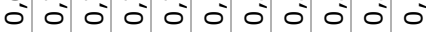

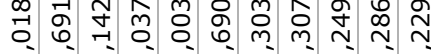
† o ơt

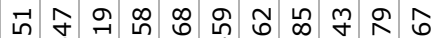

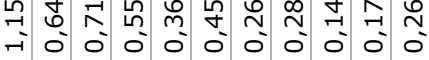
ชู่

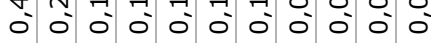

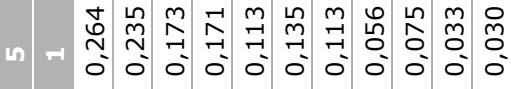

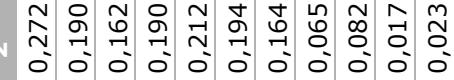

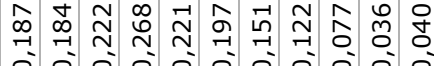

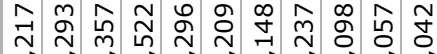
స̃.

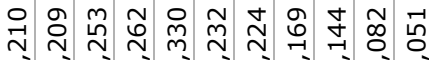

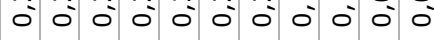
吕

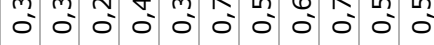

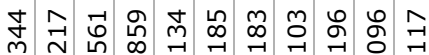
o.

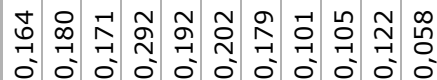

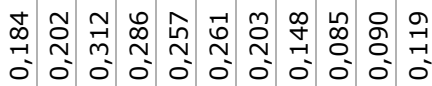

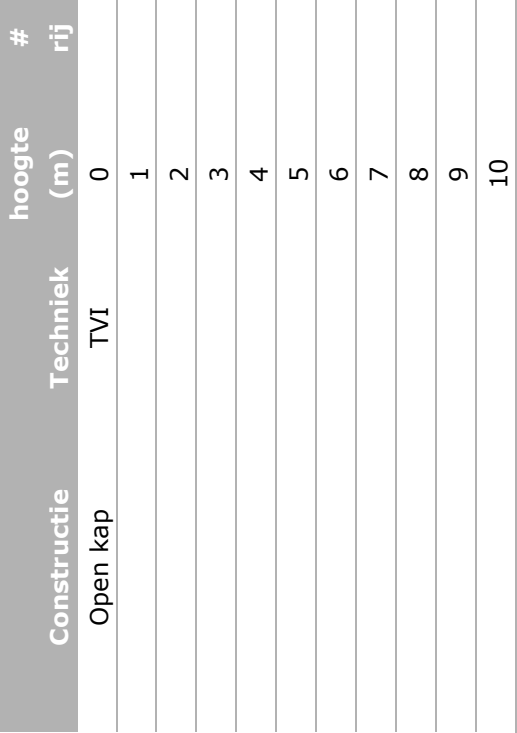




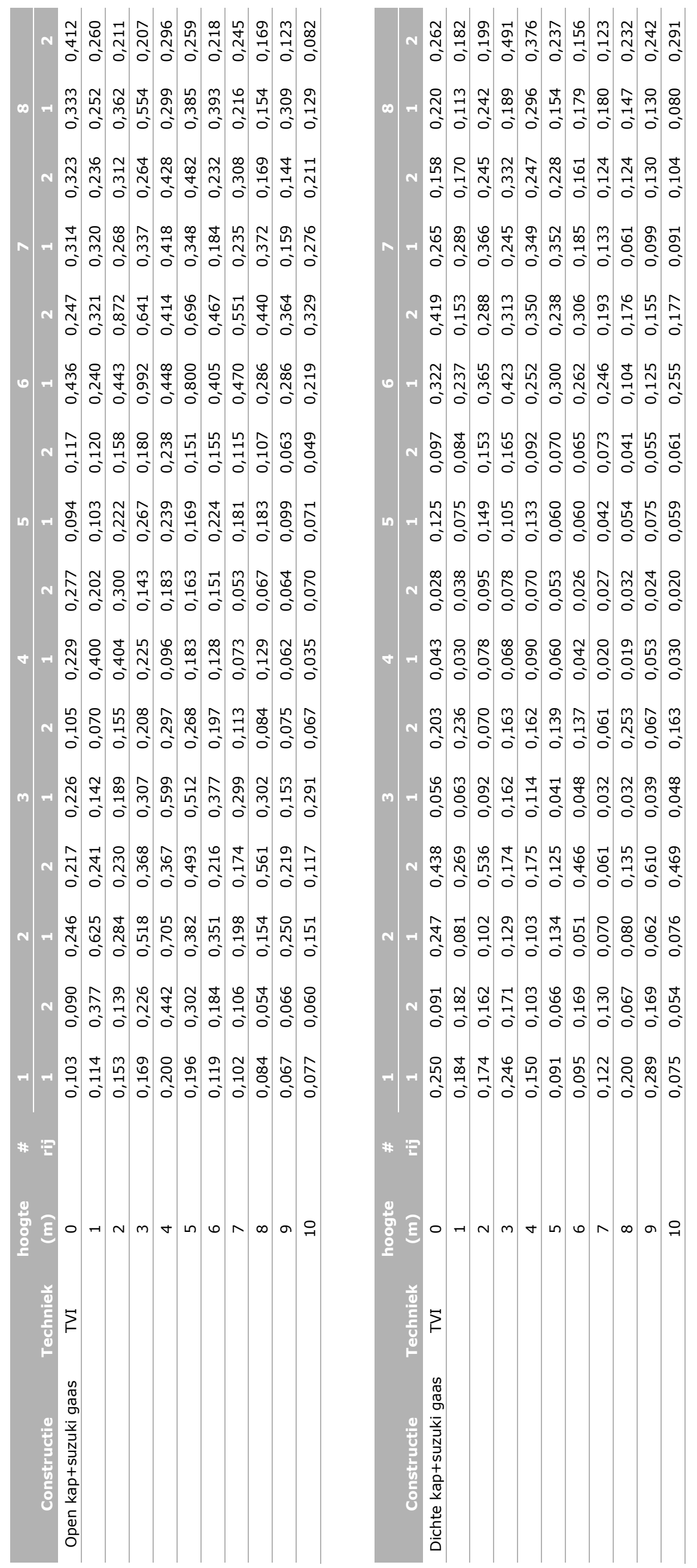


Correspondentie adres voor dit rapport: Postbus 16

6700 AA Wageningen

T 0317480700

www.wur.nl/plant-research

Rapport WPR-960
De missie van Wageningen University \& Research is 'To explore the potential of nature to improve the quality of life'. Binnen Wageningen University \& Research bundelen Wageningen University en gespecialiseerde onderzoeksinstituten van Stichting Wageningen Research hun krachten om bij te dragen aan de oplossing van belangrijke vragen in het domein van gezonde voeding en leefomgeving. Met ongeveer 30 vestigingen, 5.000 medewerkers en 12.000 studenten behoort Wageningen University \& Research wereldwijd tot de aansprekende kennisinstellingen binnen haar domein. De integrale benadering van de vraagstukken en de samenwerking tussen verschillende disciplines vormen het hart van de unieke Wageningen aanpak. 



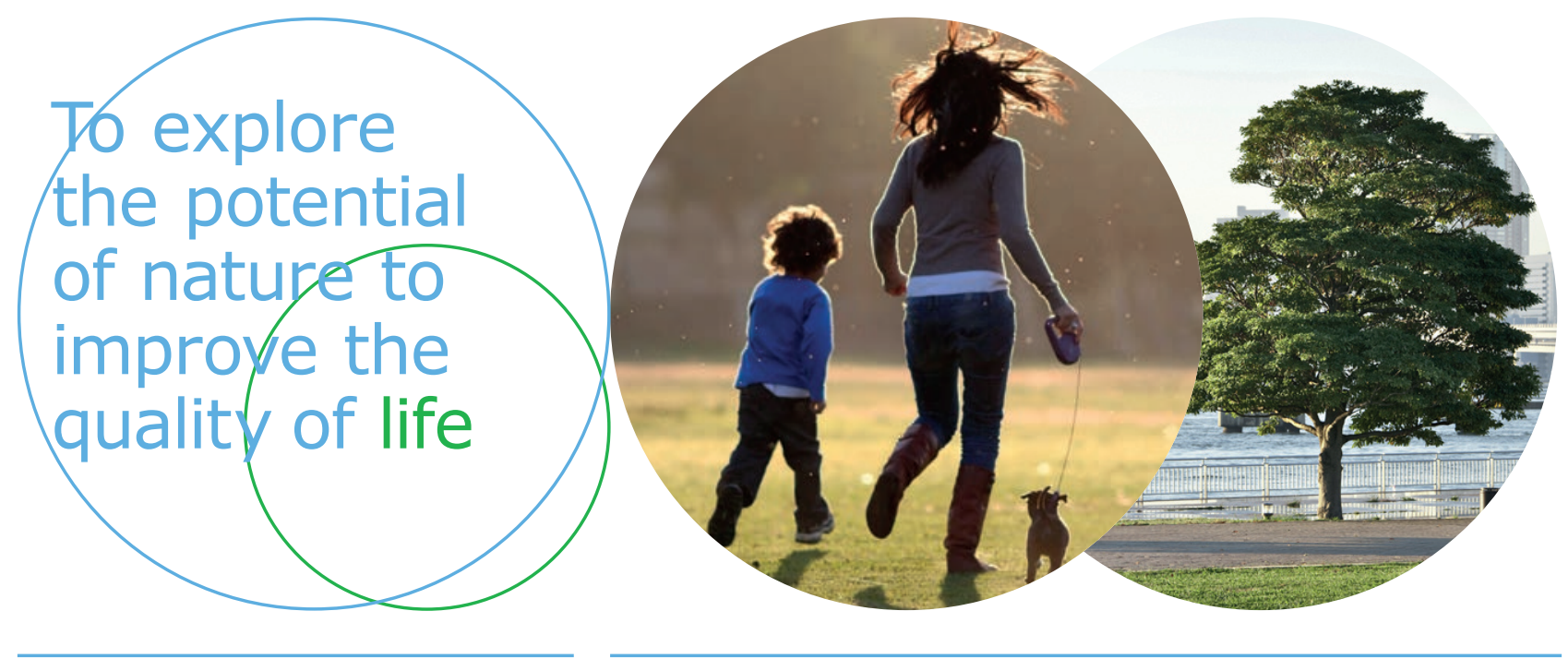

Corresponding address for this report: Postbus 16

6700 AA Wageningen

T 0317480700

www.wur.nl/plant-research

Rapport WPR-960
De missie van Wageningen University \& Research is 'To explore the potential of nature to improve the quality of life'. Binnen Wageningen University \& Research bundelen Wageningen University en gespecialiseerde onderzoeksinstituten van Stichting Wageningen Research hun krachten om bij te dragen aan de oplossing van belangrijke vragen in het domein van gezonde voeding en leefomgeving. Met ongeveer 30 vestigingen, 5.000 medewerkers en 12.000 studenten behoort Wageningen University \& Research wereldwijd tot de aansprekende kennisinstellingen binnen haar domein. De integrale benadering van de vraagstukken en de samenwerking tussen verschillende disciplines vormen het hart van de unieke Wageningen aanpak. 